This item was submitted to Loughborough's Research Repository by the author.

Items in Figshare are protected by copyright, with all rights reserved, unless otherwise indicated.

\title{
Wintertime indoor temperatures in social housing dwellings in England and the impact of dwelling characteristics
}

PLEASE CITE THE PUBLISHED VERSION

https://doi.org/10.1016/j.enbuild.2021.110837

PUBLISHER

Elsevier

VERSION

AM (Accepted Manuscript)

\section{PUBLISHER STATEMENT}

This paper was accepted for publication in the journal Energy and Buildings and the definitive published version is available at https://doi.org/10.1016/j.enbuild.2021.110837

\section{LICENCE}

CC BY-NC-ND 4.0

\section{REPOSITORY RECORD}

Beizaee, Arash, Johanna Morey, and Ali Badiei. 2021. "Wintertime Indoor Temperatures in Social Housing Dwellings in England and the Impact of Dwelling Characteristics". Loughborough University.

https://hdl.handle.net/2134/14034944.v1. 
1 Wintertime Indoor Temperatures in Social Housing Dwellings in

2 England and the Impact of Dwelling Characteristics

3 Arash Beizaee ${ }^{*}$ Johanna Morey ${ }^{b}$ Ali Badiei ${ }^{c}$

$4 \quad{ }^{a}$ School of Architecture, Building and Civil Engineering, Loughborough University, Loughborough,

5 Leics., LE11 3TU, UK

6 b Institute of Energy and Sustainable Development, De Montfort University, Leicester, Leics., LE1

$79 \mathrm{BH}, \mathrm{UK}$

$8{ }^{\mathrm{C}}$ Centre for Sustainable Energy Technologies, Energy and Environment Institute, University of Hull,

9 Hull, HU6 7RX, UK

10 *Corresponding author: a.beizaee@lboro.ac.uk

Keywords: Indoor temperature; Dwelling characteristic; Heating season; Winter; Social housing; English homes

\section{Abstract}

This paper presents one of the largest wintertime indoor temperature surveys of English social housing dwellings. Half hourly temperatures were measured in living rooms and main bedrooms of 124 social housing dwellings located in central England. Indoor temperatures were analysed for two distinct periods of "heating season" and "winter" during the assumed occupied hours of 08:00-20:00 for living rooms and 20:00-08:00 for bedrooms. The mean living room and bedroom temperatures when occupied were $19.0^{\circ} \mathrm{C}$ and $18.7^{\circ} \mathrm{C}$ respectively during the heating season and $18.6^{\circ} \mathrm{C}$ and $18.2^{\circ} \mathrm{C}$ during the winter. The mean living room temperature during the winter was $2.4^{\circ} \mathrm{C}$ lower than the minimum living room temperature of $21^{\circ} \mathrm{C}$ recommended by the World Health Organisation (WHO). The living rooms and bedrooms spent $39 \%$ and $46 \%$ of their occupied hours respectively below $18^{\circ} \mathrm{C}$ which is recommended by the Public Health England as a reasonable minimum indoor temperature for homes in winter. Older properties built before 1982 were found at significantly higher risk of low temperatures. The study discusses the need for a method to assess the risk of underheating in homes particularly in social housing dwellings which accommodate vulnerable groups of people who are often less able to tolerate or to adapt to low temperatures.

\section{Introduction}

\footnotetext{
Abbreviations: ASHP, Air Source Heat Pump; BRE, Building Research Establishment; Cl, Confidence Interval; EFUS, Energy Follow-Up Survey; EHS, English Housing Survey; EPC, Energy Performance Certificate; GSHP, Ground Source Heat Pump; LA, Local Authority; NHS, National Health Service; ONS, Office of National Statistics; RSL, Registered Social Landlords; SAP, Standard Assessment Procedure; SD, Standard Deviation; WHO, World Health Organisation
} 
The UK Office of National Statistics (ONS) estimated that in winter 2018-2019, there were over 23,000 excess deaths in England and Wales (ONS, 2019a). Poor housing conditions and fuel poverty ${ }^{1}$, which are among the key contributors to underheated dwellings in winter, together with preexisting health conditions, and their complex relations with each other have been the prevailing reasons behind the UK's higher number of wintertime excess deaths and illnesses compared to other European countries (Healy, 2003; Fowler et al., 2015; Liddell and Morris, 2010). Existing research has established that the groups of the population most vulnerable to adverse impacts of cold indoor temperatures are elderly (people over 65 years of age), very young (children under 15 years of age), and people with pre-existing health conditions (particularly chronic cardiovascular and respiratory disease) (Jevons et al., 2016).

The social housing sector is the largest contributor to the UK's affordable housing scheme with approximately five million homes across the UK, representing $17 \%$ of all homes in the domestic sector (ONS, 2019b). England has the highest number of social houses in the UK with 4.1 million homes (ONS, 2019b). In 2015, compared to the overall population, social housing in Great Britain had a considerably higher proportion of residents receiving disability benefits ( $18 \%$ cf. $6 \%$ ), a higher proportion of children under 16 years of age ( $24 \%$ cf. $18 \%)$, a higher rate of unemployment $(51 \%$ cf. $28 \%$ ) and a lower median weekly income (£276 cf. £403) (Adam et al., 2015). These figures suggest substantial vulnerability to colder indoor temperatures and lower affordability to adequately heat homes within the social housing sector. Monitoring indoor temperatures in social housing dwellings on a large scale could provide a better understanding of the extent to which these dwellings suffer from cold rooms in winter and the key factors that affect their indoor temperatures.

The World Health Organisation (WHO) recommended minimum domestic temperatures of $21^{\circ} \mathrm{C}$ for living rooms and $18{ }^{\circ} \mathrm{C}$ for bedrooms. The Cold Weather Plan for England (Public Health England, 2018) which provides advice on how to prepare for and respond to cold weather recommends $18^{\circ} \mathrm{C}$ as a reasonable minimum indoor temperature for homes in winter which poses minimal risk to the health of a sedentary person, wearing suitable clothing. The report emphasizes that the $18^{\circ} \mathrm{C}$ threshold is "particularly important for people 65 years and over or with pre-existing medical conditions" during the daytime and may be "beneficial to protect their health" overnight.

Review of the existing literature identified very few studies which have exclusively investigated wintertime indoor temperatures in English social housing dwellings. These studies were either small scale temperature monitoring studies concentrated on specific dwelling types and households (Teli

\footnotetext{
${ }^{1} \mathrm{~A}$ household is considered to be in fuel poverty when their income is below the poverty line (taking into account energy costs); and their energy costs are higher than is typical for their household type (DECC, 2013a).
} 
et al., 2016; Gupta and Kapsali, 2016) or based on socio-technical surveys rather than monitoring indoor temperatures (Jones et al., 2016) (Table 1). Studies beyond those of social housing provide further understanding of the wintertime temperatures in English dwellings. The 2011 Energy FollowUp Survey (EFUS 2011) (DECC, 2013b) consisted of a follow-up interview survey of a subset of households first visited as part of the 2010/11 English Housing Survey (EHS) as well as indoor temperature monitoring in a sub-sample of these households. To date, at least four different studies have analysed indoor temperature data collected as a part of EFUS 2011 (Table 1). Various relationships have been investigated including mean heating season temperatures and dwelling characteristics (DECC, 2013b), mean wintertime temperatures and dwelling and household characteristics (Hamilton et al., 2017), the proportion of temperatures at least at $18^{\circ} \mathrm{C}$ and dwelling characteristics (Huebner et al., 2019), and age and long term disability (Huebner et al., 2018). The analysis of the EFUS 2011 dataset showed that for the whole sample, including social housing dwellings, there were large proportions of properties with temperatures below $18^{\circ} \mathrm{C}$ during the winter months (Hamilton et al., 2017). Properties with higher Energy Performance Certificate (EPC) ratings were generally warmer, as were newer dwellings, although the newest were not necessarily the warmest (DECC, 2013b). Living rooms and bedrooms in social housing dwellings ${ }^{2}$ were on average warmer than owner-occupied and private rented dwellings (DECC, 2013b). Tenure, wall type and EPC rating have been identified as dwelling characteristics requiring further investigation with regards to their impact on the number of hours reaching at least $18^{\circ} \mathrm{C}$ (Huebner et al., 2019).

Other large monitoring studies of wintertime indoor temperatures in English homes did not provide any analysis of indoor temperatures for their sub-samples of social housing dwellings. Huebner et al. (2013a; and 2013b) investigated measured indoor temperatures and heating patterns for a nationally representative sample of English homes and compared against established UK building stock model assumptions. Kane et al. (2015) investigated heating patterns in 249 homes in Leicester, England. Oreszczyn et al. (2006) reported wintertime indoor temperatures in a subset of 1604 dwellings with low-income households at five urban areas in England, in an effort to quantify the impact of dwelling and household characteristics on temperature variations. Table 1 provides a summary of wintertime indoor temperature studies in English dwellings.

Table 1: Summary of wintertime indoor temperature studies in English dwellings highlighting sample size, number of social housing dwellings, location, investigation period and data collection methods

\footnotetext{
2 EFUS 2011 present social housing dwellings under two categories of Local Authorities (LA) and Registered Social Landlords (RSL). LA are the main providers of social housing for people who cannot afford their own accommodation. RSL are independent housing organisations, mostly housing associations which offer similar types of housing as local authorities.
} 


\begin{tabular}{|c|c|c|c|c|c|}
\hline Study & Sample Size & Social housing size & Location & Investigation period & Data collection methods \\
\hline $\begin{array}{l}\text { Teli et al. } \\
(2016)\end{array}$ & 18 & $\begin{array}{l}18 \text { (low income } \\
\text { tenants in a tower } \\
\text { block) }\end{array}$ & Portsmouth & $\begin{array}{l}\text { Winter (Mar to Apr) } \\
2015\end{array}$ & $\begin{array}{l}\text { Questionnaire surveys and } \\
\text { temperature loggers in } \\
\text { bedrooms and living room }\end{array}$ \\
\hline $\begin{array}{l}\text { Gupta and } \\
\text { Kapsali } \\
\text { (2016) }\end{array}$ & 6 & $\begin{array}{l}6 \text { (in three } \\
\text { sustainable housing } \\
\text { developments) }\end{array}$ & $\begin{array}{l}\text { South East } \\
\text { England }\end{array}$ & $\begin{array}{l}\text { Heating season } 2013 \\
\text { (Oct-Apr) }\end{array}$ & $\begin{array}{l}\text { Interview surveys and } \\
\text { temperature loggers }\end{array}$ \\
\hline $\begin{array}{l}\text { Jones et al. } \\
\text { (2016) }\end{array}$ & 537 & 537 & Plymouth & $\begin{array}{l}\text { Winter } 2015 \\
\text { (Unidentified months) }\end{array}$ & Socio-technical surveys \\
\hline $\begin{array}{l}\text { EFUS } 2011 \\
\text { (DECC, } \\
2013 b)\end{array}$ & $\begin{array}{l}2616 \text { interview } \\
\text { surveys, } 823 \\
\text { temperature } \\
\text { loggers }\end{array}$ & $\begin{array}{l}235 \text { (Local } \\
\text { authority, } \\
\text { Registered social } \\
\text { landlord) }\end{array}$ & England & Feb 2011 to Jan 2012 & $\begin{array}{l}\text { Interview surveys, temperature } \\
\text { loggers in living room, main } \\
\text { bedrooms, and hallway }\end{array}$ \\
\hline $\begin{array}{l}\text { Hamilton } \\
\text { et al. } \\
(2017)\end{array}$ & $\begin{array}{l}823 \\
\text { (used data from } \\
\text { the EFUS 2011) }\end{array}$ & $\begin{array}{l}235 \text { (Local } \\
\text { authority, } \\
\text { Registered social } \\
\text { landlord) }\end{array}$ & England & $\begin{array}{l}\text { Winter: Feb } 2011 \text { to Jan } \\
2012 \text { (standardised to } \\
\text { outdoor air } \\
\text { temperatures of } 0^{\circ} \mathrm{C} \text {, } \\
5^{\circ} \mathrm{C} \text { and } 10^{\circ} \mathrm{C} \text { ) }\end{array}$ & $\begin{array}{l}\text { Interview surveys, temperature } \\
\text { loggers in the living room, the } \\
\text { main bedrooms, and the } \\
\text { hallway. }\end{array}$ \\
\hline $\begin{array}{l}\text { Huebner et } \\
\text { al. (2018; } \\
\text { 2019) }\end{array}$ & $\begin{array}{l}635 \\
\text { (part of data } \\
\text { used for the } \\
\text { EFUS 2011) }\end{array}$ & $\begin{array}{l}176 \text { (Local } \\
\text { authority, } \\
\text { Registered social } \\
\text { landlord) }\end{array}$ & England & $\begin{array}{l}\text { Winter: Feb 2011, Dec } \\
\text { 2011, Jan } 2012\end{array}$ & $\begin{array}{l}\text { Interview surveys, temperature } \\
\text { loggers in the living room, the } \\
\text { main bedrooms, and the } \\
\text { hallway. }\end{array}$ \\
\hline $\begin{array}{l}\text { Huebner et } \\
\text { al. (2013a) }\end{array}$ & 248 & 29 (estimated) & England & $\begin{array}{l}\text { Winter: Oct } 2007 \text { to Feb } \\
2008\end{array}$ & $\begin{array}{l}\text { Interview surveys, temperature } \\
\text { loggers in the living room and } \\
\text { the main bedroom }\end{array}$ \\
\hline $\begin{array}{l}\text { Huebner et } \\
\text { al. }(2013 b)\end{array}$ & 248 & Not identified & England & $\begin{array}{l}\text { Winter: Nov } 2007 \text { to Jan } \\
2008\end{array}$ & $\begin{array}{l}\text { Interview surveys, temperature } \\
\text { loggers in the living room only }\end{array}$ \\
\hline $\begin{array}{l}\text { Kane et al. } \\
(2015)\end{array}$ & 249 & Not identified & Leicester & $\begin{array}{l}\text { Winter: Dec } 2009 \text { to } \\
\text { Feb } 2010\end{array}$ & $\begin{array}{l}\text { Interview surveys and } \\
\text { temperature loggers in the } \\
\text { living room and the main } \\
\text { bedroom }\end{array}$ \\
\hline $\begin{array}{l}\text { Oreszczyn } \\
\text { et al. } \\
(2006)\end{array}$ & 1604 & Not identified & $\begin{array}{l}\text { Birmingham, } \\
\text { Manchester, } \\
\text { Liverpool, } \\
\text { Newcastle, } \\
\text { Southampton }\end{array}$ & $\begin{array}{l}\text { Winters 2001-2003 (for } \\
\text { outside temperatures } \\
\text { of }<5^{\circ} \mathrm{C} \text { ) }\end{array}$ & Temperature loggers \\
\hline
\end{tabular}

90 With very few existing surveys of wintertime indoor temperatures in English domestic buildings and

91 with no large-scale study to concentrate on indoor temperature variations within the social housing

92 sector, there is a substantial research gap to understand the wintertime temperatures in social

93 housing dwellings which house groups of the population who are more vulnerable to cold

94 conditions. 
The aim of this study is to investigate variations in wintertime indoor temperatures in English social housing dwellings and to quantify the extent to which these variations are explained by dwelling characteristics. The study presents the findings from one of the largest temperature monitoring surveys of English social housing dwellings. For the first time, indoor temperatures are analysed and presented for two distinct periods of "heating season" and "winter" (see section 2.5) to allow wider comparison with the existing temperature monitoring surveys. The findings of this research are of great importance in identifying social housing dwellings which are at risk of low indoor temperatures during the colder months and provide guidance for policy makers and social housing developers to prioritise dwellings which need attention for refurbishment.

\section{Methods}

EMH homes, which is one of the largest social housing providers in the Midlands region of England, conducted an energy and temperature monitoring survey in over 180 of their properties over a period of four years between 2013-17. The aim was to better understand the energy performance of their homes and to identify and prioritise tenants at risk of fuel poverty. The research presented here focuses on living room and bedroom temperatures measured in 124 properties with valid data available for a full heating season from $1^{\text {st }}$ October 2014 to $30^{\text {th }}$ April $2015^{3}$. The properties were distributed across 32 different postcode areas of the English Midlands. The maximum distance between all postcodes was $134 \mathrm{~km}$ (Figure 1).

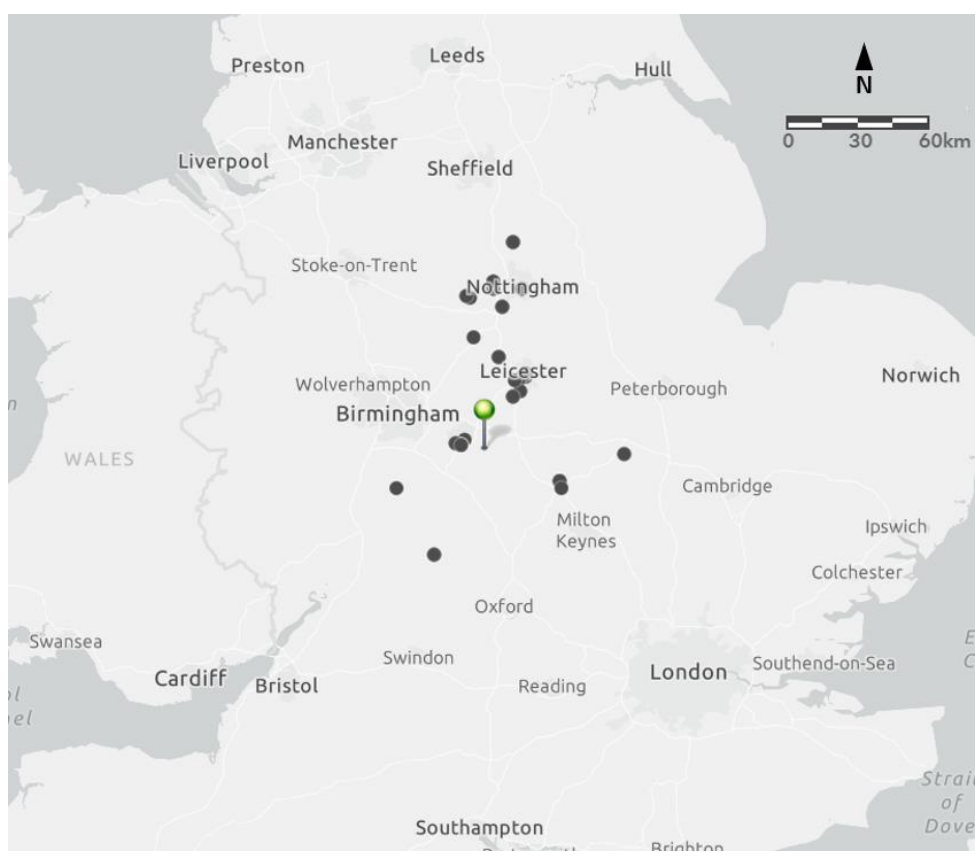

\footnotetext{
${ }^{3}$ Analysis of summertime temperatures and overheating risk for a very similar sample of properties have already been published (see Morey et al., 2020).
} 
114 Figure 1: Location of properties in the final data set within the UK. Dots represent one or more 115 properties by postcode district. Stickpin shows the location of Church Lawford weather station which 116 provided ambient temperature data used in this study.

\section{2.1. Sample composition}

118 A final data set of $124 \mathrm{EMH}$ dwellings were obtained from an initial sample of 181 dwellings

119 following a data cleaning process (section 2.4). The initial sample of 181 dwellings were selected by

120 EMH with the aim to cover a wide range of dwelling types and ages in the study. All dwelling

121 characteristics, including dwelling type, built year, EPC rating (also known as Standard Assessment

122 Procedure (SAP) rating; BRE, 2012), floor area, wall type and built form, were provided by EMH

123 homes from in-house records. SAP ratings (ranging from 0 to 100 with a higher value associated with

124 a better energy performance) are divided into bands $A$ to $G$ with ' $A$ ' rated properties the best

125 performers.

126 Table 2 compares the composition of the final dataset with the national stock profiles for social 127 housing dwellings and all dwellings presented in the English Housing Survey (EHS) 2017 (MHCLG, 128 2020). Compared to English social housing stock, the EMH data set had an over-representation of 129 recently built dwellings and bungalows and an under-representation of older properties and flats.

130 The average SAP rating of the EMH data set was 67 points, equal to the English social housing 131 average and higher than the average of 62 for English dwellings (MHCLG, 2020). The average floor 132 area of the EMH data set was $67 \mathrm{~m}^{2}$, almost equal to the English social housing average of $66 \mathrm{~m}^{2}$ 133 and remarkably lower than average of $94 \mathrm{~m}^{2}$ for English dwellings (ibid).

134 Table 2: Comparison of dwelling in the EMH final dataset with both social and all dwellings in English 135 Housing Survey (EHS) 2017 (MHCLG, 2020)

\begin{tabular}{lccc}
\hline Characteristic & $\begin{array}{c}\text { EMH } \\
\text { dwellings (\%) } \\
n=124\end{array}$ & $\begin{array}{c}\text { EHS Social } \\
\text { dwellings (\%) } \\
n=4,072,000\end{array}$ & $\begin{array}{l}\text { EHS all } \\
\text { tenures (\%) } \\
n=23,950,000\end{array}$ \\
\hline $\begin{array}{l}\text { Dwelling type } \\
\text { Detached }\end{array}$ & 2.4 & 0.4 & 17.1 \\
Semi-detached & 17.1 & 17.1 & 25.5 \\
Terraced & 27.6 & 26.8 & 28.0 \\
Flat & 26.8 & 45.0 & 20.3 \\
Bungalow & 26.0 & 10.7 & 9.2 \\
& & & \\
Built year & & & \\
Pre 1919 & 4.1 & 6.5 & 20.8 \\
1919-44 & 4.9 & 10.5 & 15.8 \\
1945-64 & 17.1 & 31.1 & 19.1 \\
1965-80 & 32.5 & 27.0 & 19.6 \\
1981-90 & 16.3 & 8.0 & 7.9 \\
Post 1990 & 25.2 & 16.8 & 16.8 \\
& & & \\
SAP rating & & & \\
A/B & & 2.2 & 1.3 \\
& 7.6 & &
\end{tabular}




\begin{tabular}{lccc} 
C & 45.7 & 50.0 & 28.8 \\
D & 37.0 & 41.3 & 50.5 \\
E & 8.7 & 5.2 & 14.4 \\
F & 1.1 & 0.9 & 3.8 \\
G & - & - & - \\
& & \\
Total floor area & & \\
Less than $50 \mathrm{~m}^{2}$ & 24.4 & 26.5 & 9.6 \\
$50-69 \mathrm{~m}^{2}$ & 28.5 & 32.0 & 21.8 \\
$70-89 \mathrm{~m}^{2}$ & 34.1 & 31.3 & 27.9 \\
$90-109 \mathrm{~m}^{2}$ & 12.2 & 7.4 & 16.8 \\
$110 \mathrm{~m}^{2}$ or more & 0.8 & 2.9 & 23.8 \\
\hline
\end{tabular}

137 The types of heating system found in EMH dwellings were not proportionally similar to those found

138 in EHS for the social housing sector. Only $70 \%$ of the EMH dwellings had a central heating system

139 compared to $92 \%$ in the English social housing sector and across all English dwellings. The proportion

140 of EMH dwellings with storage heaters ${ }^{4}(25 \%)$ was considerably higher than the English social

141 housing sector (7\%) and all English dwellings (5\%). 56\% of EMH dwellings were heated using gas and

$14244 \%$ were heated using electricity. In properties with electric heating, 60\% had storage heaters, 31\%

143 Air Source Heat Pump (ASHP), 4\% Ground Source Heat Pump (GSHP) and 5\% other types of electric

144 heating.

\subsection{Ambient temperature conditions}

146 Hourly dry bulb temperature data was obtained from Church Lawford weather station (Latitude:

147 52.3584, Longitude: -1.32987) recorded in the MIDAS dataset (Met Office, 2006). The weather

148 station was selected by considering both proximity to all 124 dwellings and availability of hourly

149 ambient temperature data ${ }^{5}$. The maximum distance between a postcode and the Church Lawford

150 weather station was $87 \mathrm{~km}$.

151 Figure 2 shows the frequency of different ambient air temperatures ranges during the heating

152 season. The heating season considered in this study (October to April; see section 2.5) represented a

153 typical heating season for both the Midlands region and the whole of England. The average

154 temperature during the heating season was $6.8^{\circ} \mathrm{C}$ which is very close to the average heating season

155 temperatures for the Midlands and England for the last 10 years and slightly higher than the average

156 for the last 100 years (Figure 3). The winter period considered in this study (December to February;

157 see section 2.5) included the three coldest months during the heating season (Figure 3).

\footnotetext{
${ }^{4}$ Storage heater is an electric heater that utilises off-peak electricity, usually available at night, and store thermal energy which will be then released during the day to heat the space.

${ }^{5}$ There were only three hours of missing dry bulb temperature data which were replaced with the average ambient temperatures for the hours before and after.
} 


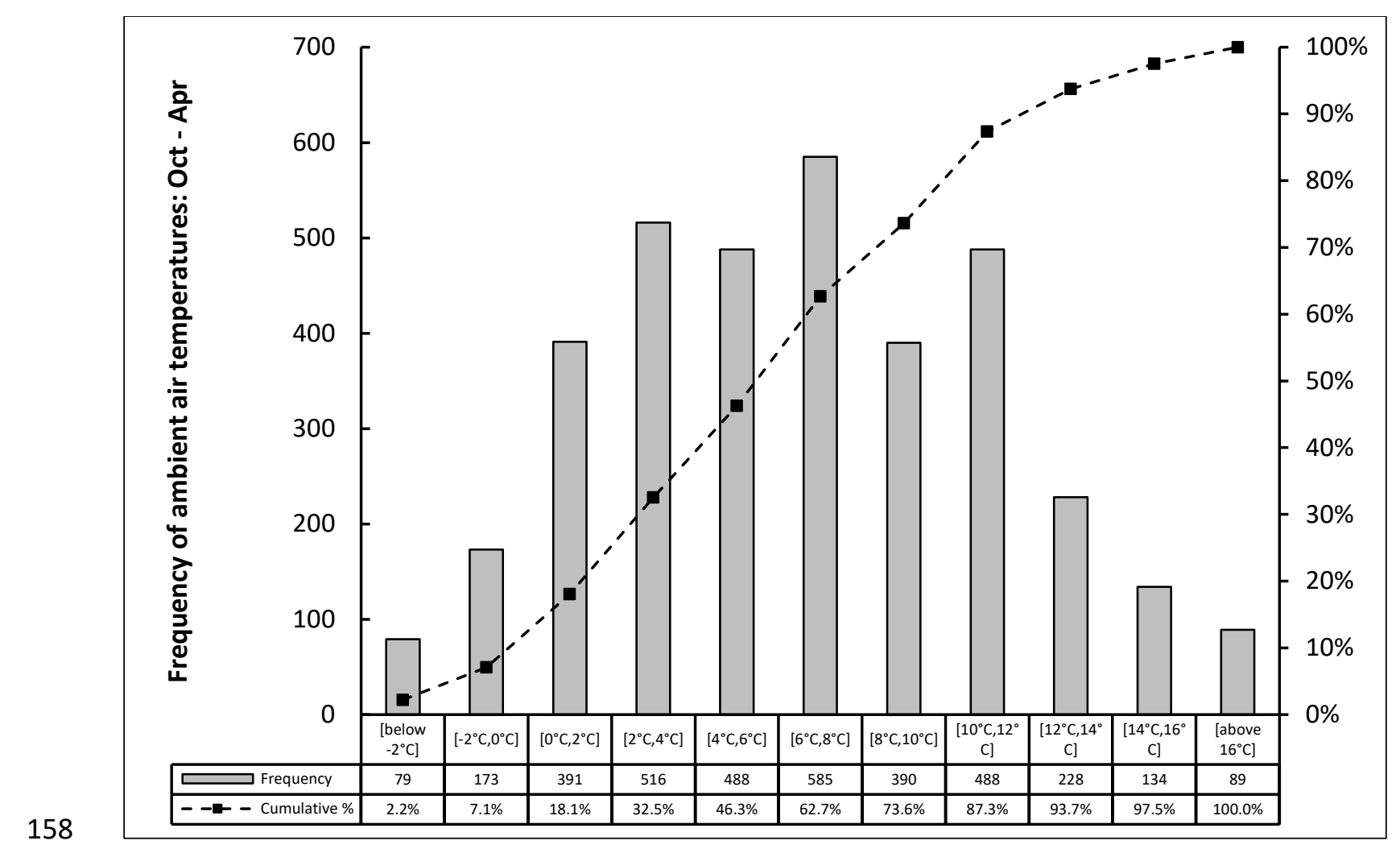

159 Figure 2: Frequency of ambient air temperatures during Oct 2014-Apr 2015 along with the cumulative frequency curve

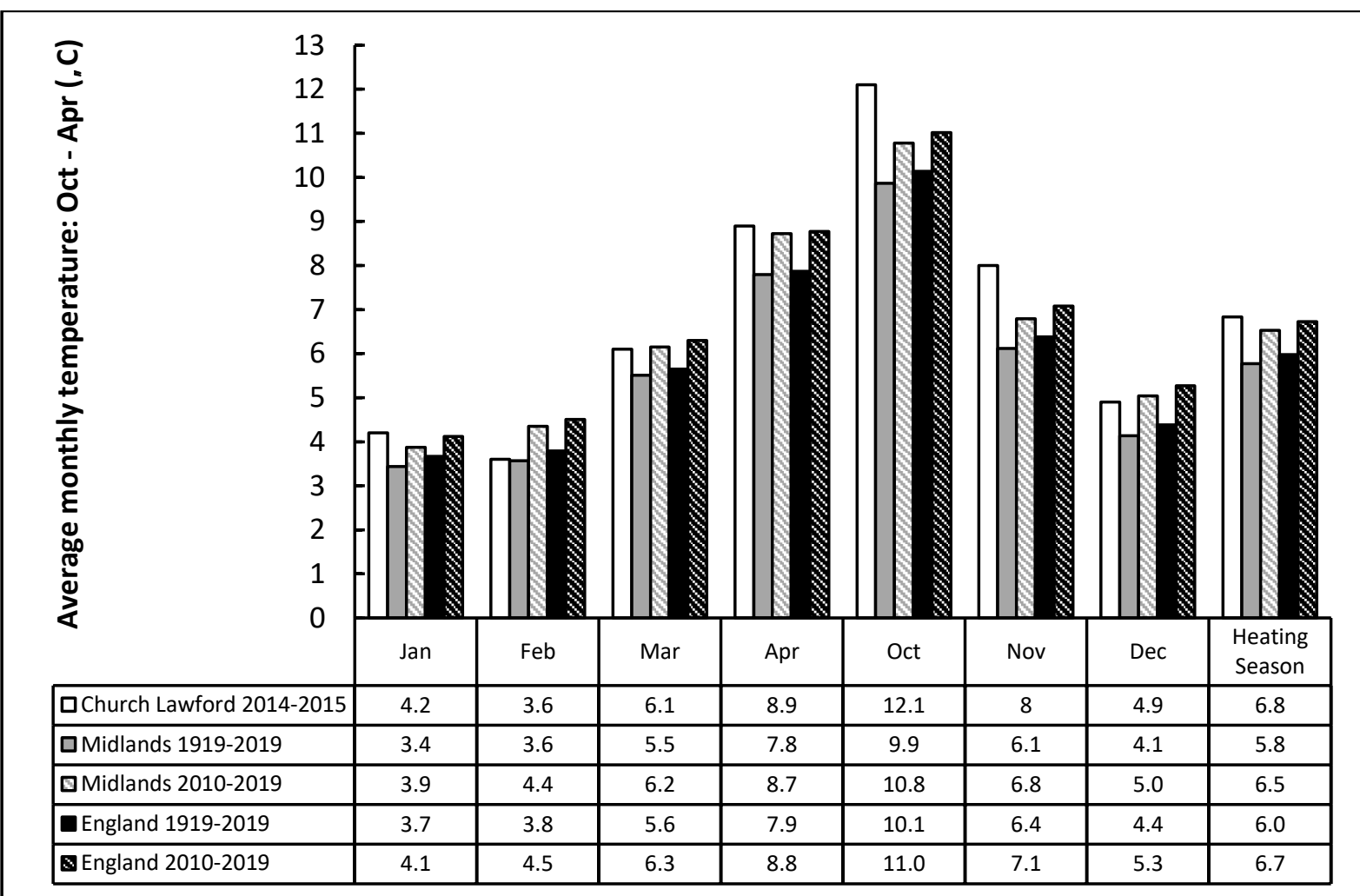


Figure 3: Average monthly temperatures for Church Lawford weather station (2014-15) and historical average monthly temperatures for the Midlands and England

\subsection{Indoor temperature data collection}

Living room and the main bedroom temperatures were measured every half hour using Orsis CO2SS Combined Sensors (Table 3). The sensors transmit data via radio frequency to a server where the data was retrieved (Orsis, 2020).

Table 3: Technical information for Orsis CO2SS Combined Sensors used in this study to measure living room and bedroom temperatures (Orsis, 2020)

\begin{tabular}{ll}
\hline Parameter & Characteristics \\
\hline Temperature accuracy & $+/-1^{-} \mathrm{C}$ \\
Temperature range & $-25^{\circ} \mathrm{C} \sim+55^{-} \mathrm{C}$ \\
Operating temperature & $-25^{\circ} \mathrm{C} \sim+70^{-} \mathrm{C}$ \\
Data stored & 2500 records \\
Data retention time & $8 \sim 52$ days \\
\hline
\end{tabular}

The Orsis CO2SS Combined Sensors were placed in the living room and main bedroom of each dwelling by a trained team. The sensors were typically placed upon shelves, away from windows or doors and out of sunlight and any source of heat. Additional checks were carried out by the authors to assess the reliability and accuracy of the temperature data by placing additional calibrated temperature sensors in a sub-sample of dwellings. A comparison by Morey et al. (2020) concluded that the temperatures recorded by Orsis sensors provide a reasonable measurement of room temperature.

\subsection{Data cleaning}

Data cleaning was performed with the following objectives:

a) To remove from the data set any room with a considerable proportion (>=4\%) of missing and/or erroneous temperature readings during the heating season.

b) To identify and remove long periods (i.e. over 3 days) when a dwelling was unoccupied and unheated. This was to avoid misrepresentation of internal temperature variation in occupied dwellings during the heating season.

Before the start of data cleaning, half hourly temperatures recorded at 169 living rooms and 171 bedrooms from 181 dwellings were resampled to hourly in order to match with the hourly external 


\begin{tabular}{|l|l|}
\hline \multicolumn{2}{|c|}{ Initial dataset $(\mathrm{n}=181)$} \\
\hline 169 Living rooms & 171 Bedrooms \\
\hline
\end{tabular}

Step1: Removing rooms with more than $4 \%$ of missing or erroneous (i.e. negative) temperature recordings $(n=130)$

108 Living room 112 Bedrooms

Step2: Visual inspection to remove rooms with unreliable data and long periods (i.e.over 3 days) which were deemed to be unoccupied and unheated $(n=124)$

191 Figure 4: Data cleaning procedures and number of dwellings, living rooms and bedrooms at each stage

Step 1: Rooms with more than $4 \%$ of missing or negative temperature recordings were removed from the sample ${ }^{6}$ and any missing value with run lengths of 4 hours and under were replaced with linearly interpolated values ${ }^{7}$.

Step 2: Hourly living room and bedroom temperatures for each dwelling were plotted against ambient temperature for the whole heating season and were visually inspected to identify any errors and anomalies. Where errors were clearly evident, the room was excluded from the data set. Six sensors showed large step changes in the temperature profiles, suggesting that the sensors had been moved from their original location or that the tenants had moved out of the house at some point during the monitoring period and the house had become unoccupied. Figure 5 shows an example of temperatures recorded in an excluded living room where a large step change is evident. This suggest that either the house was unoccupied from February onwards or the sensor was removed from where it was originally located. In addition, another six sensors recorded temperatures which were very similar to the ambient temperature suggesting that the sensors had been moved and placed somewhere outside of the house. In three cases when there was any

\footnotetext{
${ }^{6} 4 \%$ limit was considered reasonable in view of a balance between retaining properties and the degree of completeness of data for a particular room.

${ }^{7}$ A maximum run length of 4 hours was considered as a short enough period within a daily cycle not to lead to major misrepresentation of internal temperature variation with the linear interpolation procedure.
} 
uncertainty as to whether the data was real or anomalous it remained in the data set. Multiple opinions were sought for critical cases.

209

In addition, visual inspection identified relatively long periods when rooms were deemed to be unoccupied and unheated (e.g. Figure 6). These "holiday periods" were removed from the data set when they were longer than three days and otherwise remained in the data set. Equivalent "holiday periods" were found in living rooms and bedrooms from individual dwellings where temperature data for both rooms were available $(n=11)$. In addition, holiday periods were found in three dwellings where only bedroom temperature data was available.

The final data set contained 104 living rooms and 104 bedrooms from a total of 124 dwellings. 84 dwellings had data for both rooms, 20 had data for living room only, and 20 had data for bedroom only.

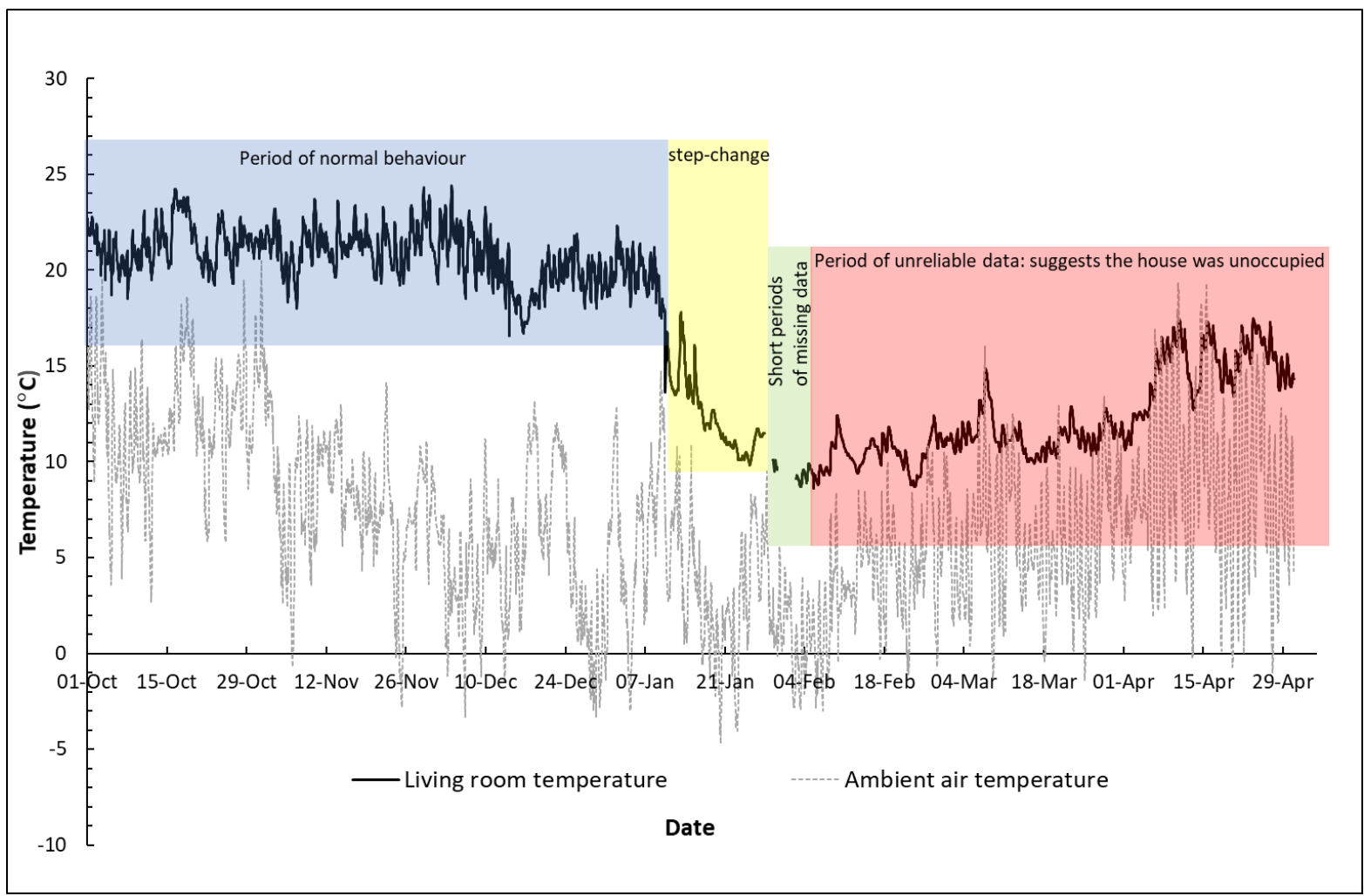

Figure 5: Example of temperatures recorded in an excluded living room 


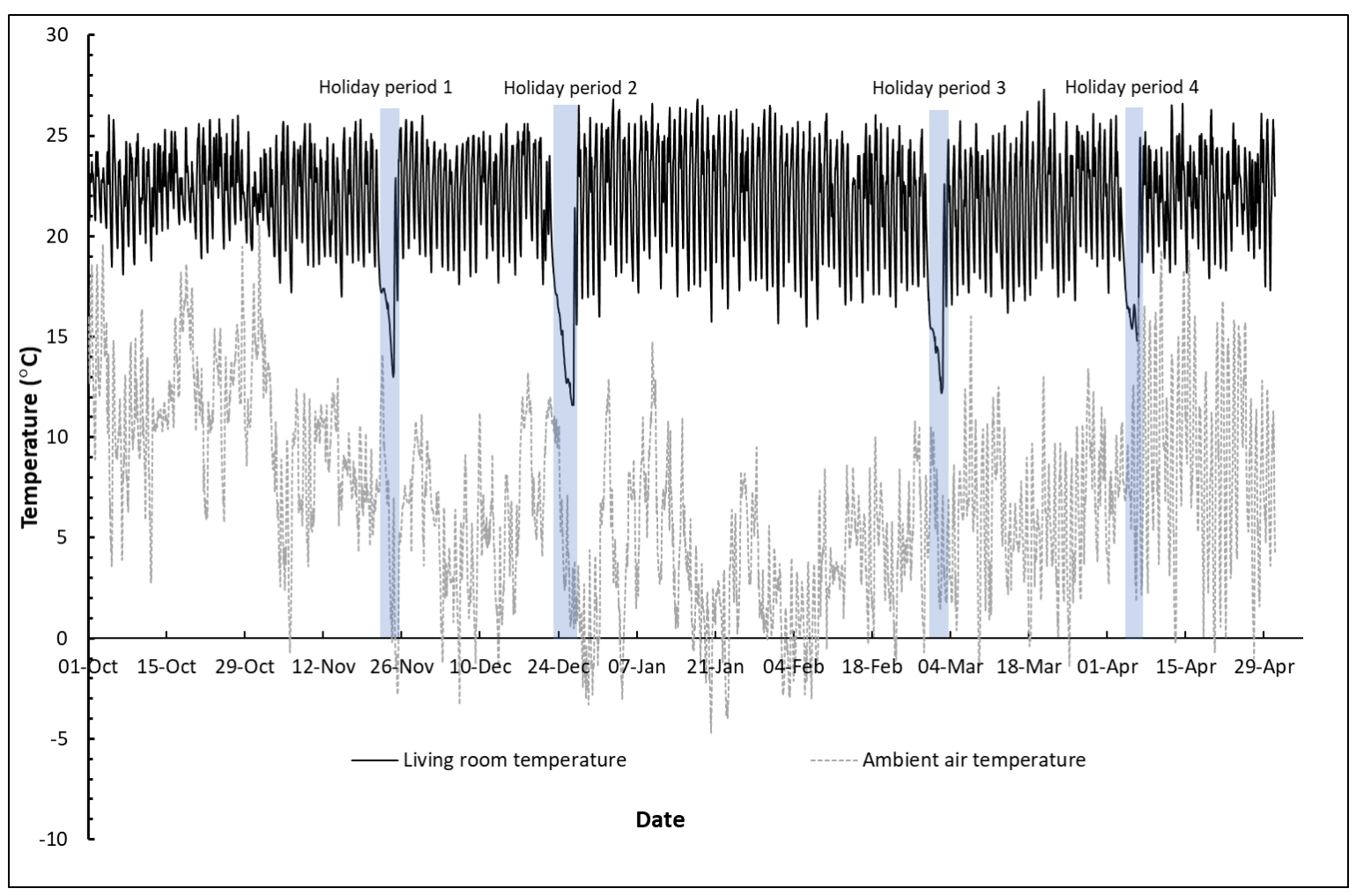

Figure 6: Example of hourly temperatures in a living room with four distinct periods where the room was deemed to be unoccupied and unheated

\subsection{Heating season and winter classifications}

224

In this study "heating season" is defined as $1^{\text {st }}$ October to 30th April according to the Energy Follow up Survey (DECC, 2013b) which highlighted that the majority of households in the UK turn on their heating systems on a regular daily basis in October and switch off sometime in March or April.

In order to provide further insights into indoor temperatures during colder than average conditions, data was also analysed for the "winter" defined as $1^{\text {st }}$ December to $28^{\text {th }}$ February. The winter months had average temperatures below the average external temperature during the heating season (section 2.2).

\subsection{Occupied hours and minimum temperature threshold}

Living rooms were assumed to be occupied from $8 \mathrm{am}$ to $8 \mathrm{pm}$, and bedrooms to be occupied from $8 \mathrm{pm}$ to $8 \mathrm{am}$, according to the Oreszczyn et al. (2006). $18^{\circ} \mathrm{C}$ was used in this study as a reasonable minimum temperature threshold during the occupied hours for both living rooms and bedrooms as recommended by the Cold Weather Plan for England (Public Health England, 2018).

\subsection{Calculated parameters and statistical analysis}


$R$ version 3.5.1 (The $R$ foundation, 2018) was used to perform all the statistical analysis presented in this paper. For each dwelling, mean living room and bedroom temperatures during the heating season and the winter were calculated for the occupied hours of each room. Mean, 95\% Confidence Interval (Cl), Standard Deviation (SD), median, minimum (Min) and maximum (Max) of the calculated means for the individual dwellings were presented for the whole sample and for dwellings in various dwelling characteristic categories (Table 4). In addition, the percentage of occupied hours below the minimum temperature threshold of $18^{\circ} \mathrm{C}$ was also calculated and presented (Table 4). Mean achieved temperatures during the heating season and the winter were calculated for each living room and bedroom as the mean of the daily maximum temperatures recorded in the living room or the bedroom (Kane et al., 2015; Shipworth et al., 2010). Summary statistics similar to Table 4 were also presented for the mean achieved temperatures (Table 5).

248 To compare mean occupied hours temperatures and mean achieved temperatures, a one-way 249 analysis of variance (ANOVA) was performed in SPSS (IBM, 2017) for each property category, for 250 each room type and period (Table 6). Where this showed statistical significance between groups $(p<$ $0.1)^{8}$, a post hoc Tukey HSD test was performed. To determine differences between property subcategories based on the percentage of occupied hours below $18^{\circ} \mathrm{C}$, the non-parametric KruskalWallis test was performed upon the number of hours below $18^{\circ} \mathrm{C}$ (i.e. the data underlying the percentage of occupied hours below $18^{\circ} \mathrm{C}$ ) since this data displayed non-normal distributions per sub-category (Table 7). Where this showed statistical significance between groups $(p<0.1)^{9}$ pairwise comparisons were performed using Dunn's procedure adjusted with the Bonferroni correction for multiple tests were performed. Sub-categories with fewer than five properties were not included in the analyses and only results with post hoc significance $p<0.1$ are reported.

\section{Results}

\subsection{Mean heating season and winter temperatures}

During the heating season, mean living room temperatures varied from $13.8^{\circ} \mathrm{C}$ to $24.3^{\circ} \mathrm{C}$ with an average of $19.0^{\circ} \mathrm{C}$ across the $104 \mathrm{dwellings}$ while the mean bedroom temperatures varied from $13.2^{\circ} \mathrm{C}$ to $25.1^{\circ} \mathrm{C}$ with an average of $18.7^{\circ} \mathrm{C}$ (Table 4). Figure 7 presents percentage of rooms with mean heating season and winter temperature below different temperature thresholds. $32.7 \%$ of

\footnotetext{
${ }^{8}$ All except two of the Table 6 comparisons had an ANOVA between groups significance at $p<0.05$; the exceptions were Living Room Heating (Winter Occupied Hours, $p=0.060$ ), Bedroom Floor Space (Winter Occupied Hours, $p=0.052$ )

${ }^{9} \mathrm{All}$ except four of the Table 7 comparisons had Kruskal-Wallis between groups significance at $p<0.05$; the exceptions were Living Room Heating (Heating Period, $p=0.064$ ), (Winter, $p=0.057$ ), Bedroom Floor Space (Winter, $p=0.056$ ), Bedroom Wall Construction (Winter, $\mathrm{p}=0.060$ )
} 
living rooms and $42.3 \%$ of bedrooms had mean heating season temperatures which were below the minimum recommended temperature threshold of $18^{\circ} \mathrm{C}$ (Figure 7).

267 During the winter, while larger temperature variations were observed, the mean living room and bedroom temperatures were generally lower. The mean living room temperatures varied from $12.7^{\circ} \mathrm{C}$ to $25.3^{\circ} \mathrm{C}$ with an average of $18.6^{\circ} \mathrm{C}$ while the mean bedroom temperatures varied from $10.9^{\circ} \mathrm{C}$ to $25.8^{\circ} \mathrm{C}$ with an average of $18.2^{\circ} \mathrm{C}$ (Table 4). $79.8 \%$ of the living room had a mean temperature which was below the minimum temperature of $21^{\circ} \mathrm{C}$ recommended by WHO (Figure 7). $39.4 \%$ of the living rooms and $46.2 \%$ of the bedrooms had mean winter temperatures below $18^{\circ} \mathrm{C}$ (Figure 7). Only $22.1 \%$ of the living rooms were on average maintained at $21^{\circ} \mathrm{C}$ and above as recommended by WHO (WHO, 2003) while $68.3 \%$ of bedrooms were at $17^{\circ} \mathrm{C}$ and above (Figure 7).

275

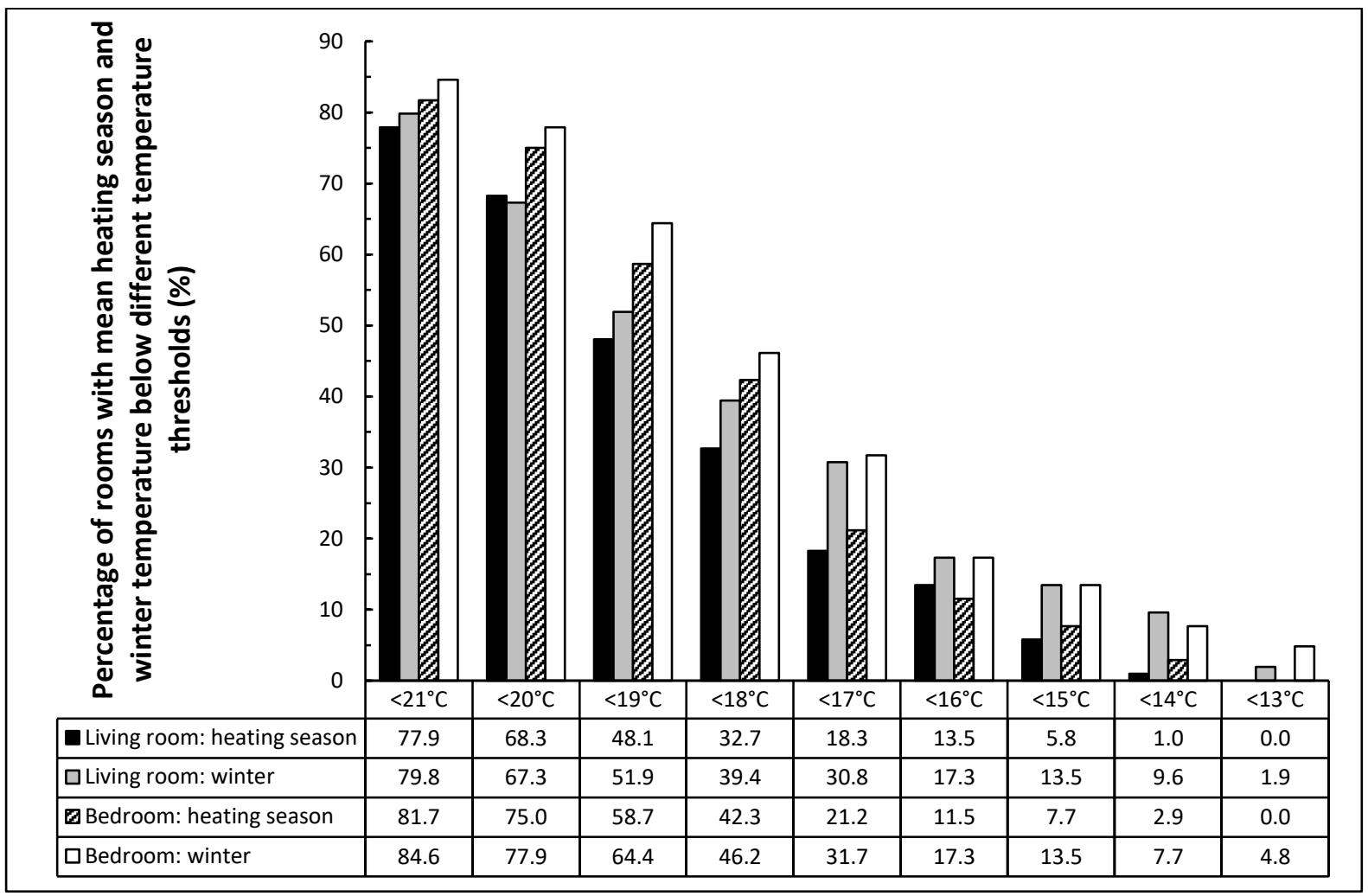

277 Figure 7: Percentage of rooms with mean heating season and winter temperature (for occupied 278 hours) below different temperature thresholds (\%) 


\begin{tabular}{|c|c|c|c|c|c|c|c|c|c|c|c|c|c|c|c|c|c|}
\hline & \multicolumn{8}{|c|}{ Living room } & \multicolumn{9}{|c|}{ Bedroom } \\
\hline & \multirow[b]{2}{*}{$n$} & \multirow[b]{2}{*}{ Mean } & \multicolumn{2}{|c|}{ Mean occupied hours } & \multicolumn{3}{|c|}{ e $m p$ e a $t u r$} & \multirow{2}{*}{$\begin{array}{l}\text { Percentage o } \\
\text { occupied hou } \\
\text { b e I o w }\end{array}$} & & \multirow[b]{2}{*}{$n$} & \multirow[b]{2}{*}{ Mean } & \multirow{2}{*}{$\begin{array}{c}\text { Me a n } \\
95 \% \mathrm{Cl}\end{array}$} & \multicolumn{2}{|c|}{ occupied } & \multirow{2}{*}{$\frac{\mathrm{h} \circ \mathrm{urs}}{\operatorname{Min}}$} & \multirow{2}{*}{$\frac{t \text { e } m \text { r }}{\text { Max }}$} & \multirow{2}{*}{$\begin{array}{l}\text { Percentage of } \\
\text { occupied hours } \\
\text { b e I o w 1 }\end{array}$} \\
\hline & & & $95 \% \mathrm{Cl}$ & SD & Median & Min & Max & & & & & & SD & Median & & & \\
\hline \multirow{2}{*}{ ALL PROPERTIES } & \multirow{2}{*}{104} & 19.0 & $(18.6,19.5)$ & 2.4 & 19.1 & 13.8 & 24.3 & 33.4 & & \multirow{2}{*}{104} & 18.7 & $(18.2,19.2)$ & 2.4 & 18.5 & 13.2 & 25.1 & 38.7 \\
\hline & & 18.6 & $(18.1,19.2)$ & 2.8 & 18.8 & 12.7 & 25.3 & 38.6 & & & 18.2 & $(17.7,18.8)$ & 2.9 & 18.2 & 10.9 & 25.8 & 45.9 \\
\hline PROPERTY TYPE & & & & & & & & & & & & & & & & & \\
\hline & & 18.8 & $(18.2,19.5)$ & 2.2 & 19.0 & 13.8 & 24.2 & 33.9 & & & 18.3 & $(17.7,19.0)$ & 2.3 & 18.0 & 13.2 & 24.2 & 44.2 \\
\hline House & 46 & 18.5 & $(17.7,19.2)$ & 2.6 & 18.8 & 12.7 & 24.8 & 39.1 & & 48 & 17.6 & $(16.8,18.5)$ & 2.8 & 17.6 & 10.9 & 24.8 & 55.8 \\
\hline & & 18.8 & $(17.9,19.7)$ & 2.3 & 19.3 & 14.9 & 23.3 & 36.6 & & & 18.9 & $(18.1,19.7)$ & 2.0 & 18.5 & 13.8 & 23.1 & 33.4 \\
\hline Bungalow & 30 & 18.2 & $(17.2,19.2)$ & 2.8 & 18.5 & 13.4 & 23.3 & 43.0 & & 27 & 18.7 & $(17.9,19.6)$ & 2.1 & 18.6 & 11.8 & 22.5 & 36.5 \\
\hline Flat & 28 & 19.7 & $(18.6,20.7)$ & 2.7 & 19.4 & 14.6 & 24.3 & 28.9 & & 29 & 19.1 & $(18.1,20.2)$ & 2.8 & 19.0 & 14.5 & 25.1 & 34.5 \\
\hline SAP RATING & & & & & & & & & & & & & & & & & \\
\hline$B$ & & 19.4 & $(18.3,20.5)$ & 0.9 & 19.6 & 18.3 & 20.5 & 19.1 & & & 19.0 & $(16.2,21.8)$ & 2.3 & 19.7 & 15.6 & 21.5 & 26.6 \\
\hline B & 5 & 18.9 & $(17.3,20.6)$ & 1.3 & 19.2 & 17.3 & 20.2 & 27.0 & & 5 & 18.6 & $(15.9,21.4)$ & 2.2 & 19.2 & 15.0 & 20.5 & 29.0 \\
\hline & & 19.0 & $(18.0,19.9)$ & 2.7 & 18.9 & 13.8 & 24.1 & 37.0 & & & 19.0 & $(18.1,19.9)$ & 2.6 & 18.4 & 14.9 & 25.1 & 38.8 \\
\hline C & 35 & 18.6 & $(17.5,19.7)$ & 3.2 & 18.9 & 12.7 & 24.8 & 42.1 & & 35 & 18.6 & $(17.5,19.6)$ & 3.1 & 17.9 & 12.8 & 25.8 & 44.4 \\
\hline D & 30 & 18.4 & $(17.5,19.3)$ & 2.5 & 18.0 & 14.9 & 24.3 & 43.7 & & 32 & 18.6 & $(17.6,19.6)$ & 2.7 & 18.4 & 13.2 & 23.7 & 39.8 \\
\hline D & 30 & 17.7 & $(16.6,18.9)$ & 3.0 & 17.3 & 13.4 & 25.3 & 52.6 & & 32 & 18.2 & $(17.0,19.3)$ & 3.3 & 18.3 & 10.9 & 24.8 & 46.2 \\
\hline & & 18.3 & $(16.0,20.5)$ & 1.8 & 18.5 & 15.5 & 19.9 & 37.5 & & 6 & 17.5 & $(15.1,19.8)$ & 2.3 & 17.9 & 14.0 & 20.0 & 52.2 \\
\hline $\mathrm{E}$ & 5 & 17.6 & $(14.5,20.8)$ & 2.5 & 18.7 & 13.5 & 19.5 & 43.7 & & 6 & 16.8 & $(13.7,19.8)$ & 2.9 & 17.6 & 12.2 & 19.8 & 59.2 \\
\hline YEAR OF BUILD & & & & & & & & & & & & & & & & & \\
\hline pro 1066 & 22 & 18.1 & $(17.2,18.9)$ & 2.0 & 18.5 & 15.0 & 22.5 & 43.5 & & 27 & 18.5 & $(17.4,19.6)$ & 2.7 & 18.3 & 13.2 & 25.1 & 42.1 \\
\hline 1966 - 1981 & 38 & 18.1 & $(17.1,19.1)$ & 2.9 & 18.0 & 12.7 & 23.3 & 47.8 & & 33 & 17.5 & $(16.7,18.3)$ & 2.3 & 17.6 & 12.8 & 21.9 & 56.9 \\
\hline & & 20.3 & $(19.5,21.2)$ & 2.2 & 20.1 & 15.4 & 24.3 & 19.3 & & & 19.4 & $(18.4,20.3)$ & 2.6 & 19.3 & 14.0 & 24.2 & 32.7 \\
\hline 1982- 1995 & 29 & 20.2 & $(19.2,21.1)$ & 2.5 & 20.1 & 14.8 & 25.3 & 21.1 & & 30 & 18.9 & $(17.8,20.0)$ & 3.0 & 18.7 & 12.2 & 24.4 & 37.1 \\
\hline & & 19.3 & $(18.0,20.5)$ & 2.2 & 19.3 & 14.8 & 23.0 & 26.7 & & & 19.3 & $(18.2,20.3)$ & 1.9 & 19.0 & 15.3 & 22.0 & 26.8 \\
\hline post 1995 & 15 & 18.8 & $(17.3,20.2)$ & 2.7 & 19.1 & 13.1 & 23.1 & 31.4 & & 14 & 18.8 & $(17.4,20.1)$ & 2.4 & 18.9 & 13.2 & 22.2 & 32.3 \\
\hline WALL CONSTRUCTIC & & & & & & & & & & & & & & & & & \\
\hline & & 19.0 & $(18.4,19.5)$ & 2.4 & 18.9 & 13.8 & 24.3 & 34.9 & & & 18.8 & $(18.3,19.3)$ & 2.4 & 18.6 & 13.2 & 25.1 & 37.2 \\
\hline Filled cavity & 90 & 18.5 & $(17.9,19.1)$ & 2.9 & 18.7 & 12.7 & 25.3 & 40.2 & & 87 & 18.4 & $(17.8,19.0)$ & 2.9 & 18.5 & 10.9 & 25.8 & 42.9 \\
\hline & & 20.1 & $(17.7,22.4)$ & 2.2 & 20.7 & 15.8 & 21.8 & 16.9 & & & 18.7 & $(17.0,20.5)$ & 1.9 & 18.3 & 16.1 & 21.7 & 36.0 \\
\hline Unfilled cavity & 6 & 19.9 & $(17.6,22.1)$ & 2.1 & 20.6 & 15.7 & 21.6 & 17.4 & & 7 & 18.4 & $(16.7,20.1)$ & 1.9 & 18.2 & 15.3 & 21.1 & 41.8 \\
\hline & & 19.3 & NA & NA & NA & NA & NA & 3.5 & & & 19.7 & $(-31.7,71.1)$ & 5.7 & 19.7 & 15.6 & 23.7 & 46.5 \\
\hline Solid - Uninsulated & 1 & 18.8 & NA & $N A$ & NA & $N A$ & $N A$ & 6.8 & & 2 & 19.7 & $(-45.3,84.7)$ & 7.9 & 19.7 & 14.6 & 24.8 & 49.7 \\
\hline & 6 & 19.8 & $(17.7,21.9)$ & 2.0 & 20.6 & 17.2 & 21.5 & 25.1 & & 7 & 17.7 & $(16.7,18.8)$ & 1.1 & 18.0 & 16.3 & 19.0 & 50.3 \\
\hline Solid - Insulated & 6 & 19.4 & $(16.8,22.1)$ & 2.5 & 20.1 & 16.1 & 21.8 & 32.7 & & 7 & 16.5 & $(15.0,18.0)$ & 1.6 & 17.2 & 14.1 & 18.2 & 77.0 \\
\hline FLAT LEVEL & & & & & & & & & & & & & & & & & \\
\hline & & 19.0 & $(17.1,21.0)$ & 3.2 & 18.5 & 14.7 & 24.3 & 40.3 & & & 19.3 & $(17.5,21.0)$ & 2.9 & 19.4 & 14.5 & 25.1 & 33.0 \\
\hline Ground floor & 13 & 18.4 & $(16.0,20.8)$ & 3.9 & 17.9 & 12.9 & 25.3 & 49.3 & & 13 & 19.0 & $(16.8,21.1)$ & 3.6 & 19.0 & 12.8 & 25.8 & 36.8 \\
\hline & 7 & 21.1 & $(19.2,22.9)$ & 2.0 & 20.9 & 18.5 & 23.9 & 11.0 & & 8 & 18.6 & $(16.2,21.0)$ & 2.9 & 18.4 & 14.9 & 23.8 & 40.5 \\
\hline Mid floor & 7 & 21.1 & $(19.2,22.9)$ & 2.0 & 21.2 & 17.8 & 24.2 & 10.6 & & 8 & 18.0 & $(15.3,20.6)$ & 3.2 & 18.5 & 12.8 & 23.3 & 44.5 \\
\hline
\end{tabular}




\begin{tabular}{|c|c|c|c|c|c|c|c|c|c|c|c|c|c|c|c|c|}
\hline Top floor & 8 & $\begin{array}{l}19.5 \\
19.4 \\
\end{array}$ & $\begin{array}{l}(17.8,21.3) \\
(17.4,21.4) \\
\end{array}$ & $\begin{array}{l}2.1 \\
2.4\end{array}$ & $\begin{array}{l}18.9 \\
19.3\end{array}$ & $\begin{array}{l}\mathbf{1 6 . 6} \\
15.0\end{array}$ & $\begin{array}{l}23.0 \\
22.8\end{array}$ & $\begin{array}{l}25.8 \\
26.1\end{array}$ & 8 & $\begin{array}{l}19.4 \\
19.2\end{array}$ & $\begin{array}{l}(17.1,21.8) \\
(16.3,22.1)\end{array}$ & $\begin{array}{l}2.8 \\
3.5\end{array}$ & $\begin{array}{l}19.5 \\
19.0\end{array}$ & $\begin{array}{l}14.8 \\
13.3\end{array}$ & $\begin{array}{l}22.5 \\
24.0\end{array}$ & $\begin{array}{l}31.2 \\
33.8\end{array}$ \\
\hline \multicolumn{17}{|l|}{ BUILT FORM } \\
\hline \multirow{2}{*}{ Detached } & \multirow{2}{*}{5} & 18.6 & $(15.5,21.7)$ & 2.5 & 19.6 & 14.9 & 21.3 & 36.5 & \multirow{2}{*}{4} & 20.2 & $(16.6,23.8)$ & 2.3 & 20.8 & 17.2 & 22.0 & 20.0 \\
\hline & & 18.4 & $(14.6,22.3)$ & 3.1 & 19.1 & 14.3 & 22.2 & 38.6 & & 20.0 & $(16.2,23.7)$ & 2.3 & 20.5 & 17.0 & 21.9 & 21.6 \\
\hline \multirow{2}{*}{ End terrace } & \multirow{2}{*}{18} & 19.3 & $(18.1,20.5)$ & 2.5 & 19.5 & 14.9 & 24.2 & 29.7 & \multirow{2}{*}{16} & 18.6 & $(17.3,19.9)$ & 2.4 & 18.0 & 14.9 & 24.2 & 42.1 \\
\hline & & 18.7 & $(17.2,20.3)$ & 3.1 & 18.8 & 13.4 & 24.8 & 36.2 & & 18.1 & $(16.6,19.6)$ & 2.8 & 17.6 & 14.1 & 24.4 & 54.6 \\
\hline \multirow{2}{*}{ Mid terrace } & \multirow{2}{*}{18} & 18.6 & $(17.5,19.7)$ & 2.2 & 18.1 & 15.1 & 22.8 & 41.0 & \multirow[b]{2}{*}{21} & 18.7 & $(17.9,19.4)$ & 1.7 & 18.0 & 15.6 & 22.5 & 38.4 \\
\hline & & 18.1 & $(16.8,19.4)$ & 2.6 & 17.7 & 13.4 & 23.2 & 48.7 & & 18.0 & $(17.1,19.0)$ & 2.0 & 17.8 & 14.1 & 21.9 & 49.0 \\
\hline \multirow[b]{2}{*}{ Semi detached } & \multirow{2}{*}{34} & 18.7 & $(17.9,19.4)$ & 2.2 & 19.0 & 13.8 & 23.3 & 34.6 & \multirow{2}{*}{32} & 18.2 & $(17.4,19.1)$ & 2.4 & 18.4 & 13.2 & 23.7 & 43.0 \\
\hline & & 18.2 & $(17.4,19.1)$ & 2.5 & 18.7 & 12.7 & 23.3 & 39.8 & & 17.7 & $(16.7,18.8)$ & 2.9 & 18.1 & 10.9 & 24.8 & 49.2 \\
\hline $\begin{array}{l}\text { Terrace (position } \\
\text { unknown) }\end{array}$ & 1 & 18.7 & NA & NA & NA & NA & NA & 28.4 & 2 & 18.3 & $(-2.2,38.9)$ & 2.3 & 18.3 & 16.7 & 20.0 & 43.7 \\
\hline \multicolumn{17}{|l|}{ FLOOR SPACE } \\
\hline \multirow{2}{*}{$<50 \mathrm{~m}^{2}$} & \multirow{2}{*}{27} & 19.0 & $(17.9,20.1)$ & 2.7 & 18.7 & 14.7 & 23.9 & 38.7 & \multirow{2}{*}{26} & 18.2 & $(17.1,19.3)$ & 2.7 & 17.6 & 13.8 & 23.8 & 47.1 \\
\hline & & 18.2 & $(17.0,19.5)$ & 3.2 & 18.0 & 12.9 & 24.2 & 47.5 & & 17.5 & $(16.2,18.8)$ & 3.1 & 17.5 & 11.8 & 23.3 & 52.4 \\
\hline \multirow{2}{*}{$50 m^{2}-69 m^{2}$} & \multirow{2}{*}{31} & 19.5 & $(18.6,20.3)$ & 2.4 & 19.6 & 15.0 & 24.3 & 28.0 & \multirow{2}{*}{31} & 19.4 & $(18.6,20.2)$ & 2.2 & 18.9 & 14.8 & 25.1 & 28.0 \\
\hline & & 19.2 & $(18.2,20.2)$ & 2.8 & 19.5 & 13.4 & 25.3 & 30.8 & & 19.3 & $(18.4,20.3)$ & 2.6 & 18.8 & 13.3 & 25.8 & 31.6 \\
\hline \multirow{2}{*}{$70 m^{2}-89 m^{2}$} & \multirow{2}{*}{35} & 18.7 & $(17.9,19.5)$ & 2.3 & 18.7 & 13.8 & 24.2 & 37.4 & 39 & 18.4 & $(17.7,19.2)$ & 2.3 & 18.3 & 13.2 & 24.2 & 42.9 \\
\hline & & 18.3 & $(17.4,19.2)$ & 2.7 & 18.4 & 12.7 & 24.8 & 44.0 & & 17.7 & $(16.8,18.6)$ & 2.8 & 17.6 & 10.9 & 24.8 & 54.5 \\
\hline & & 19.1 & $(17.7,20.6)$ & 2.0 & 19.4 & 14.9 & 21.6 & 24.8 & & 18.9 & $(17.1,20.8)$ & 2.2 & 19.4 & 14.9 & 22.0 & 32.6 \\
\hline $90 m^{2}-109 m^{2}$ & 10 & 18.9 & $(17.1,20.7)$ & 2.5 & 19.1 & 13.4 & 22.3 & 24.3 & 8 & 18.7 & $(16.5,20.9)$ & 2.6 & 19.3 & 14.1 & 21.9 & 38.3 \\
\hline HEATING $^{+}$ & & & & & & & & & & & & & & & & \\
\hline Gac & 57 & 18.6 & $(17.9,19.2)$ & 2.4 & 18.7 & 13.8 & 24.2 & 40.3 & 57 & 18.6 & $(17.9,19.2)$ & 2.4 & 18.3 & 13.2 & 24.2 & 41.6 \\
\hline ASHP & 12 & 18.6 & $(16.7,20.6)$ & 3.0 & 19.4 & 13.2 & 22.3 & 32.7 & 13 & 19.4 & $(17.4,21.4)$ & 3.3 & 18.9 & 13.2 & 25.8 & 28.8 \\
\hline & & 19.3 & $(15.5,23.0)$ & 0.4 & 19.3 & 19.0 & 19.6 & 11.4 & & 19.6 & NA & NA & NA & NA & NA & 4.7 \\
\hline GSHP & 2 & 18.6 & $(17.0,20.1)$ & 0.2 & 18.6 & 18.5 & 18.7 & 18.1 & 1 & 19.7 & $N A$ & NA & $N A$ & NA & NA & 2.9 \\
\hline & & 20.0 & $(19.1,20.8)$ & 2.2 & 19.9 & 15.4 & 24.3 & 21.9 & & 18.7 & $(17.9,19.6)$ & 2.2 & 18.6 & 14.5 & 23.1 & 38.2 \\
\hline Storage heaters & 29 & 19.6 & $(18.7,20.6)$ & 2.5 & 19.9 & 13.5 & 25.3 & 25.1 & 28 & 18.1 & $(17.1,19.1)$ & 2.6 & 17.9 & 12.8 & 22.9 & 47.3 \\
\hline & & 17.9 & NA & NA & NA & NA & NA & 48.7 & & 16.2 & $(-12.42,44.9)$ & 3.2 & 16.2 & 14.0 & 18.5 & 63.9 \\
\hline Electric Unknown & 1 & 16.8 & NA & NA & NA & $N A$ & $N A$ & 72.8 & 2 & 14.9 & $(-20.0,49.8)$ & 3.9 & 14.9 & 12.2 & 17.7 & 79.8 \\
\hline
\end{tabular}

${ }^{*}$ all the statistics presented except percentage of occupied hours below $18^{\circ} \mathrm{C}$ were calculated using the individual property means within each category. e.g. "Mean" refers to the average of the individual property means, and "Max" refers to the maximum of the individual property means. Percentage of occupied hours below $18^{\circ} \mathrm{C}$ were calculated by counting the number of occupied hours when temperatures were below $18^{\circ} \mathrm{C}$ and dividing these by total number of occupied hours.

${ }^{\dagger}$ Heating systems in two properties had been changed resulting in two different types of heating systems during the heating season. These have been removed from the "Heating" category analysis. 


\subsection{Assessment against minimum indoor temperature threshold}

287 Most living rooms and bedrooms spent a substantial proportion of occupied hours below the

288 recommended minimum temperature threshold of $18^{\circ} \mathrm{C}$ during both the heating season and the

289 winter. Living rooms spent $33.4 \%$ and $38.6 \%$ of their occupied hours below $18^{\circ} \mathrm{C}$ during the heating

290 season and the winter, respectively (Table 4). The proportion of occupied hours below $18^{\circ} \mathrm{C}$ were

291 higher for bedrooms as these were $38.7 \%$ and $45.9 \%$ for the heating season and winter, respectively

292 (Table 4). During the heating season, only six living rooms and five bedrooms had no occupied hours

293 below $18^{-} \mathrm{C}$ (Figure 8). During the winter, the number of living rooms and bedrooms with no

294 occupied hours below $18^{\circ} \mathrm{C}$ increased to 14 and 10 respectively which indicates that some

295 households started heating their homes later in the year or set-point temperatures were increased

296 during the colder months of winter. During the heating season, 63 living rooms and 76 bedrooms

297 had more than $10 \%$ of their occupied hours below $18^{\circ} \mathrm{C}$. The figures did not noticeably change for

298 the winter period with 62 living rooms and 75 bedrooms having more than $10 \%$ of occupied hours

299 below $18^{\circ} \mathrm{C}$. Whilst not a single room failed to reach the $18^{\circ} \mathrm{C}$ threshold during the heating season,

300 seven living rooms and four bedrooms never reached $18^{\circ} \mathrm{C}$ during the winter (Figure 8). 

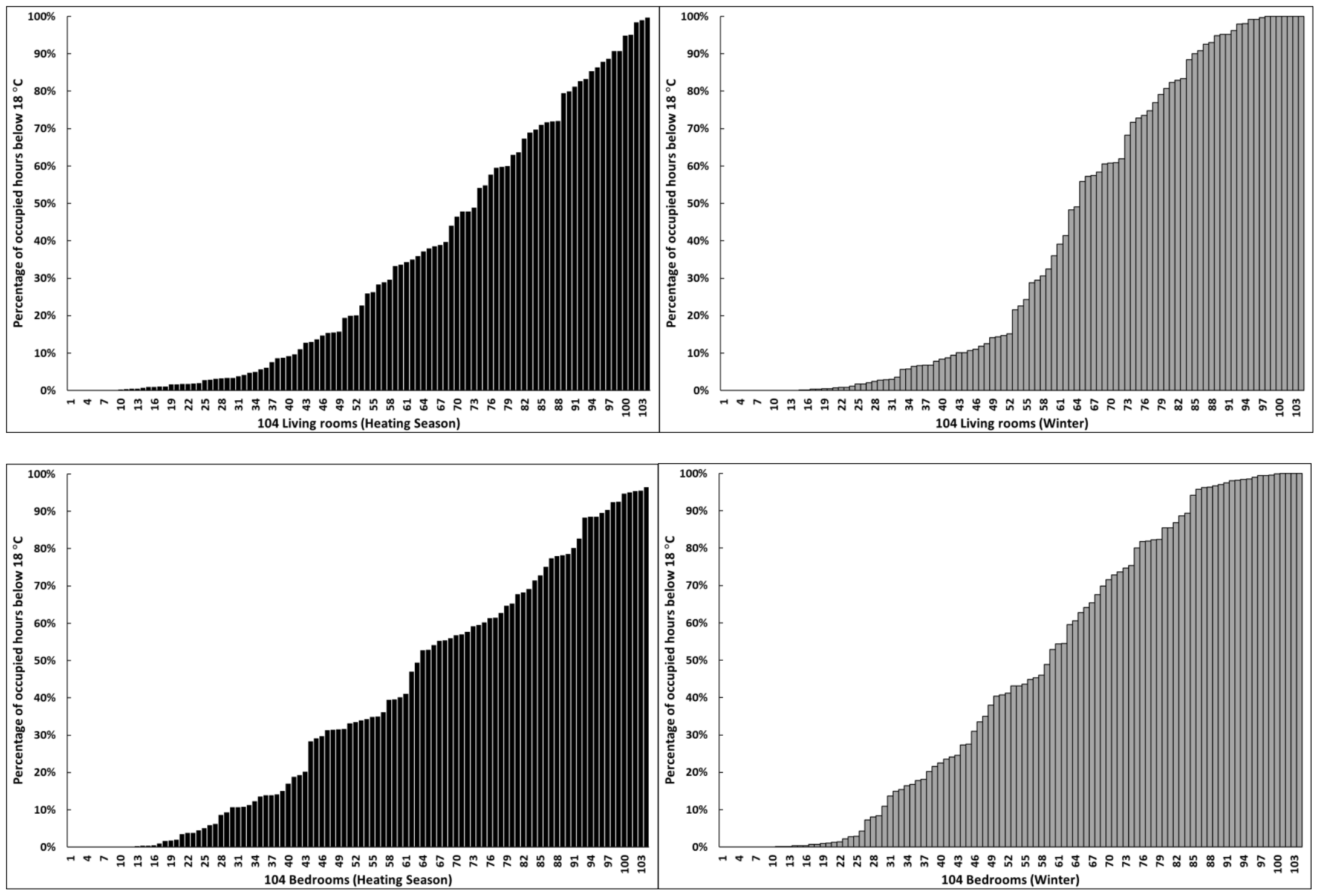
305 Mean achieved living room and bedroom temperatures varied considerably across the sample both

306 during the heating season and the winter (Table 5). During the heating season, mean achieved living

307 room and bedroom temperatures varied from $15.1^{\circ} \mathrm{C}$ to $27.1^{\circ} \mathrm{C}$ and $14.1^{\circ} \mathrm{C}$ to $26.0^{\circ} \mathrm{C}$ respectively.

308 During the winter, an even larger variation in mean achieved temperatures was observed as it varied

309 from $14.2^{\circ} \mathrm{C}$ to $30.1^{\circ} \mathrm{C}$ in living rooms and from $11.9^{\circ} \mathrm{C}$ to $27.9^{\circ} \mathrm{C}$ in bedrooms. Across the 104 living

310 rooms the average mean achieved temperatures during the heating season and the winter were

$31120.4^{\circ} \mathrm{C}$ and $20.2^{\circ} \mathrm{C}$, respectively. Across the 104 bedrooms these were $19.9^{\circ} \mathrm{C}$ and $19.6^{\circ} \mathrm{C}$ for the heating season and the winter, respectively. 


\begin{tabular}{|c|c|c|c|c|c|c|c|c|c|c|c|c|c|c|}
\hline & \multicolumn{7}{|c|}{ Living room } & \multicolumn{7}{|c|}{ Bedroom } \\
\hline & \multicolumn{7}{|c|}{ Mean achieved temperature $\left({ }^{-} \mathrm{C}\right)$} & \multicolumn{7}{|c|}{ Mean achieved temperature $\left({ }^{-} \mathrm{C}\right)$} \\
\hline & $\mathrm{n}$ & Mean & $95 \% \mathrm{Cl}$ & SD & Median & Min & $\operatorname{Max}$ & $\mathrm{n}$ & Mean & $95 \% \mathrm{Cl}$ & SD & Median & Min & Max \\
\hline \multirow{2}{*}{ ALL PROPERTIES } & 104 & 20.4 & $(20.0,20.9)$ & 2.4 & 20.5 & 15.1 & 27.1 & \multirow{2}{*}{104} & 19.9 & $(19.4,20.4)$ & 2.5 & 19.8 & 14.1 & 26.0 \\
\hline & 104 & 20.2 & $(19.6,20.7)$ & 2.9 & 20.2 & 14.2 & 30.1 & & 19.6 & $(19.0,20.2)$ & 3.0 & 19.6 & 11.9 & 27.9 \\
\hline \multicolumn{15}{|l|}{$\begin{array}{l}\text { PROPERTY TYPE } \\
\end{array}$} \\
\hline \multirow{2}{*}{ House } & 46 & 20.1 & $(19.5,20.7)$ & 2.2 & 20.0 & 15.1 & 26.3 & \multirow{2}{*}{48} & 19.4 & $(18.7,20.1)$ & 2.4 & 19.2 & 14.1 & 26.0 \\
\hline & 46 & 19.9 & $(19.1,20.6)$ & 2.5 & 19.7 & 14.2 & 26.6 & & 18.8 & $(18.0,19.7)$ & 3.0 & 18.4 & 11.9 & 26.1 \\
\hline \multirow{2}{*}{ Bungalow } & & 20.3 & $(19.4,21.1)$ & 2.3 & 20.6 & 16.2 & 25.1 & \multirow{2}{*}{27} & 20.2 & $(19.4,21.1)$ & 2.1 & 20.1 & 15.3 & 24.2 \\
\hline & 30 & 19.8 & $(18.7,20.8)$ & 2.8 & 20.3 & 14.4 & 25.3 & & 20.2 & $(19.4,21.1)$ & 2.2 & 20.0 & 13.4 & 23.7 \\
\hline \multirow{2}{*}{ Flat } & & 21.2 & $(20.1,22.3)$ & 2.8 & 20.8 & 15.5 & 27.1 & \multirow{2}{*}{29} & 20.4 & $(19.2,21.5)$ & 3.0 & 20.1 & 15.0 & 25.8 \\
\hline & 28 & 21.1 & $(19.7,22.4)$ & 3.5 & 21.2 & 14.6 & 30.1 & & 20.1 & $(18.7,21.5)$ & 3.6 & 19.9 & 13.3 & 27.9 \\
\hline \multicolumn{15}{|l|}{ SAP RATING } \\
\hline \multirow{2}{*}{ B } & & 20.5 & $(19.3,21.6)$ & 0.9 & 20.6 & 19.5 & 21.7 & \multirow[b]{2}{*}{5} & 20.1 & $(17.2,22.9)$ & 2.9 & 20.1 & 16.9 & 22.6 \\
\hline & 5 & 20.0 & $(18.4,21.5)$ & 1.3 & 19.9 & 18.6 & 21.2 & & 19.9 & $(16.8,23.1)$ & 2.5 & 19.6 & 16.5 & 23.4 \\
\hline \multirow{2}{*}{ c } & & 20.7 & $(19.7,21.7)$ & 3.0 & 20.7 & 15.1 & 27.1 & \multirow{2}{*}{35} & 20.3 & $(19.3,21.2)$ & 2.7 & 19.9 & 15.9 & 26.0 \\
\hline & 35 & 20.6 & $(19.3,21.8)$ & 3.6 & 20.9 & 14.2 & 30.1 & & 20.0 & $(18.9,21.1)$ & 3.2 & 19.5 & 13.7 & 27.9 \\
\hline \multirow[b]{2}{*}{ D } & & 19.7 & $(18.8,20.6)$ & 2.3 & 19.6 & 16.0 & 25.3 & \multirow{2}{*}{32} & 19.8 & $(18.8,20.8)$ & 2.8 & 19.8 & 14.1 & 24.9 \\
\hline & 30 & 19.1 & $(18.0,20.1)$ & 2.8 & 19.1 & 14.5 & 26.3 & & 19.5 & $(18.3,20.7)$ & 3.4 & 20.0 & 11.9 & 25.6 \\
\hline & & 19.4 & $(17.2,21.6)$ & 1.8 & 19.3 & 16.9 & 21.2 & & 18.4 & $(15.8,21.1)$ & 2.5 & 18.7 & 14.4 & 21.0 \\
\hline$E$ & 5 & 18.6 & $(15.3,22.0)$ & 2.7 & 19.4 & 14.4 & 20.9 & 6 & 17.9 & $(14.5,21.2)$ & 3.2 & 18.6 & 12.6 & 20.8 \\
\hline YEAR OF BUILD & & & & & & & & & & & & & & \\
\hline pre 1966 & & 19.3 & $(18.5,20.1)$ & 1.8 & 19.7 & 16.2 & 23.2 & 27 & 19.6 & $(18.5,20.6)$ & 2.7 & 19.8 & 14.1 & 25.8 \\
\hline pre 1966 & 22 & 18.8 & $(17.7,19.8)$ & 2.4 & 19.3 & 14.5 & 23.0 & & 19.3 & $(17.9,20.6)$ & 3.4 & 20.0 & 11.9 & 26.6 \\
\hline & & 20.1 & $(19.3,20.9)$ & 2.4 & 19.7 & 15.1 & 25.1 & & 19.4 & $(18.7,20.2)$ & 2.1 & 19.2 & 15.0 & 23.7 \\
\hline $1966-1981$ & 38 & 19.8 & $(18.9,20.7)$ & 2.9 & 19.8 & 14.2 & 25.3 & 33 & 19.0 & (18.1, 19.9) & 2.5 & 18.7 & 13.3 & 24.1 \\
\hline & & 21.7 & $(20.8,22.6)$ & 2.4 & 21.3 & 16.0 & 27.1 & & 20.5 & $(19.5,21.6)$ & 2.9 & 20.1 & 14.4 & 26.0 \\
\hline 1982- 1995 & 29 & 21.7 & $(20.6,22.8)$ & 2.9 & 21.3 & 15.3 & 30.1 & 30 & 20.2 & $(19.0,21.5)$ & 3.5 & 19.7 & 12.6 & 27.9 \\
\hline & & 20.5 & $(19.2,21.8)$ & 2.4 & 20.6 & 16.2 & 24.6 & & 20.3 & $(19.2,21.5)$ & 2.0 & 20.3 & 16.2 & 23.7 \\
\hline post 1995 & 15 & 20.1 & $(18.5,21.7)$ & 2.9 & 19.9 & 14.6 & 25.1 & 14 & 20.0 & $(18.5,21.5)$ & 2.6 & 20.0 & 14.0 & 23.6 \\
\hline WALL CONSTRUCTI & & & & & & & & & & & & & & \\
\hline & & 20.4 & $(19.8,20.9)$ & 2.5 & 20.4 & 15.1 & 27.1 & & 20.0 & $(19.5,20.6)$ & 2.6 & 19.9 & 14.1 & 26.0 \\
\hline Filled cavity & 90 & 20.1 & $(19.4,20.7)$ & 3.0 & 19.9 & 14.2 & 30.1 & 87 & 19.8 & $(19.1,20.4)$ & 3.1 & 19.7 & 11.9 & 27.9 \\
\hline & & 21.3 & $(19.3,23.3)$ & 1.9 & 21.7 & 17.6 & 22.9 & & 19.7 & $(18.0,21.5)$ & 1.9 & 20.1 & 16.9 & 22.4 \\
\hline Unfilled cavity & 6 & 21.2 & $(19.3,23.1)$ & 1.8 & 21.4 & 18.0 & 23.4 & 7 & 19.5 & $(17.7,21.2)$ & 1.9 & 20.3 & 16.2 & 21.5 \\
\hline Solid L Uninsulated & 1 & 19.9 & NA & NA & NA & NA & NA & 2 & 20.9 & $(-29.6,71.4)$ & 5.6 & 20.9 & 16.9 & 24.9 \\
\hline Solid - Uninsulated & 1 & 19.2 & NA & NA & $N A$ & $N A$ & $N A$ & 2 & 20.8 & $(-39.9,81.5)$ & 6.8 & 20.8 & 16.0 & 25.6 \\
\hline & & 20.1 & $(18.9,23.1)$ & 2.0 & 21.4 & 18.4 & 22.9 & 7 & 18.7 & $(17.7,19.8)$ & 1.1 & 19.2 & 17.5 & 20.5 \\
\hline Solid - Insulated & 6 & 20.8 & $(18.4,23.3)$ & 2.3 & 21.3 & 18.0 & 23.2 & 7 & 17.6 & $(16.1,19.0)$ & 1.6 & 18.2 & 15.4 & 19.7 \\
\hline FLAT LEVEL & & & & & & & & & & & & & & \\
\hline & & 20.3 & $(18.5,22.1)$ & 3.0 & 19.8 & 15.5 & 5.3 & & 20.5 & $(18.7,22.3)$ & 3.0 & 20.4 & 15.0 & 25.8 \\
\hline Ground floor & 13 & 19.8 & $(17.6,22.0)$ & 3.6 & 19.5 & 14.6 & 26.3 & 13 & 20.4 & $(18.1,22.6)$ & 3.7 & 20.8 & 13.3 & 26.6 \\
\hline Mid floor & 7 & 22.2 & $(20.4,23.9)$ & 1.9 & 21.4 & 20.3 & 24.9 & 8 & 19.6 & $(17.2,22.1)$ & 2.9 & 19.1 & 15.9 & 25.4 \\
\hline
\end{tabular}




\begin{tabular}{|c|c|c|c|c|c|c|c|c|c|c|c|c|c|c|}
\hline \multirow{3}{*}{ Top floor } & \multirow{3}{*}{8} & 22.2 & $(20.7,23.8)$ & 1.7 & 22.1 & 20.0 & 24.9 & \multirow{3}{*}{8} & \multirow{3}{*}{$\begin{array}{l}19.0 \\
20.9 \\
20.8\end{array}$} & \multirow{3}{*}{$\begin{array}{l}(16.4,21.6) \\
(\mathbf{1 8 . 1}, \mathbf{2 3 . 7}) \\
(17.3,24.4)\end{array}$} & \multirow{3}{*}{$\begin{array}{l}3.1 \\
3.3 \\
4.2 \\
\end{array}$} & \multirow{3}{*}{$\begin{array}{l}19.4 \\
\mathbf{2 0 . 2} \\
19.5\end{array}$} & \multirow{3}{*}{$\begin{array}{l}13.7 \\
16.3 \\
14.9\end{array}$} & \multirow{3}{*}{$\begin{array}{l}24.3 \\
25.6 \\
27.9 \\
\end{array}$} \\
\hline & & 21.8 & $(19.1,24.8)$ & 3.1 & 20.1 & 18.6 & 27.1 & & & & & & & \\
\hline & & 22.1 & $(18.7,25.6)$ & 4.1 & 20.6 & 17.1 & 30.1 & & & & & & & \\
\hline \multicolumn{15}{|l|}{ BUILT FORM } \\
\hline \multirow{2}{*}{ Detached } & \multirow{2}{*}{5} & 20.3 & $(16.9,23.6)$ & 2.7 & 20.6 & 16.2 & 23.2 & \multirow{2}{*}{4} & 21.5 & $(17.4,25.6)$ & 2.6 & 21.8 & 18.5 & 23.7 \\
\hline & & 20.1 & $(16.0,24.2)$ & 3.3 & 19.9 & 15.5 & 24.2 & & 21.5 & $(17.0,25.9)$ & 2.8 & 21.6 & 18.6 & 24.1 \\
\hline \multirow{2}{*}{ End terrace } & \multirow{2}{*}{18} & 20.6 & $(19.4,21.8)$ & 2.4 & 20.4 & 16.9 & 26.3 & \multirow{2}{*}{16} & 19.7 & $(18.4,21.0)$ & 2.5 & 19.2 & 16.4 & 26.0 \\
\hline & & 20.1 & $(18.6,21.6)$ & 3.0 & 19.8 & 14.4 & 26.6 & & 19.3 & $(17.8,20.8)$ & 2.7 & 18.5 & 15.8 & 26.1 \\
\hline \multirow{2}{*}{ Mid terrace } & \multirow{2}{*}{18} & 20.0 & $(18.9,21.1)$ & 2.2 & 19.5 & 16.0 & 24.5 & \multirow{2}{*}{20} & 19.9 & $(19.0,20.7)$ & 1.9 & 19.6 & 16.9 & 24.2 \\
\hline & & 19.7 & $(18.4,21.0)$ & 2.6 & 19.3 & 14.9 & 24.9 & & 19.4 & $(18.4,20.4)$ & 2.2 & 19.0 & 15.4 & 23.7 \\
\hline \multirow{2}{*}{ Semi detached } & \multirow{2}{*}{34} & 20.0 & $(19.3,20.8)$ & 2.2 & 20.5 & 15.1 & 25.1 & \multirow{2}{*}{31} & 19.4 & $(18.5,20.3)$ & 2.5 & 19.9 & 14.1 & 24.9 \\
\hline & & 19.7 & $(18.8,20.6)$ & 2.5 & 20.4 & 14.2 & 25.3 & & 19.1 & $(18.0,20.2)$ & 3.1 & 19.6 & 11.9 & 25.6 \\
\hline \multirow{2}{*}{ Terrace (position unknown) } & 1 & 19.4 & NA & NA & NA & NA & NA & 2 & 19.6 & $(-7.9,47.1)$ & 3.1 & 19.6 & 17.5 & 21.8 \\
\hline & & 19.9 & $N A$ & $N A$ & $N A$ & $N A$ & $N A$ & 2 & 19.3 & $(-22.9,61.6)$ & 4.7 & 19.3 & 16.0 & 22.7 \\
\hline FLOOR SPACE & & & & & & & & & & & & & & \\
\hline$<50 \mathrm{~m}^{2}$ & 27 & 20.3 & $(19.2,21.3)$ & 2.6 & 20.3 & 15.5 & 24.9 & 26 & 19.3 & $(18.1,20.4)$ & 2.8 & 18.8 & 14.4 & 25.4 \\
\hline & 27 & 19.6 & $(18.3,20.8)$ & 3.1 & 19.8 & 14.4 & 24.9 & $\angle 6$ & 18.7 & $(17.4,20.0)$ & 3.2 & 18.4 & 12.6 & 24.8 \\
\hline $50 m^{2}-69 m^{2}$ & 31 & 21.0 & $(20.0,22.0)$ & 2.6 & 20.7 & 16.0 & 27.1 & 31 & 20.8 & $(19.9,21.6)$ & 2.4 & 20. & 16.3 & 25.8 \\
\hline $50 m^{2}-69 m^{2}$ & 31 & 20.9 & $(19.7,22.2)$ & 3.3 & 20.9 & 14.5 & 30.1 & 31 & 20.9 & $(19.8,21.9)$ & 2.8 & 20.1 & 14.9 & 27.9 \\
\hline & & 20.1 & $(19.3,20.9)$ & 2.3 & 19.9 & 15.1 & 26.3 & & 19.6 & $(18.8,20.4)$ & 2.4 & 19.4 & 14.1 & 26.0 \\
\hline $70 m^{2}-89 m^{2}$ & 35 & 19.9 & $(18.9,20.8)$ & 2.7 & 20.1 & 14.2 & 26.6 & 39 & 19.0 & $(18.1,20.0)$ & 2.9 & 18.7 & 11.9 & 26.1 \\
\hline $90 m^{2}-109 m^{2}$ & & 20.5 & $(19.3,21.7)$ & 1.6 & 20.6 & 17.6 & 23.2 & 8 & 20.1 & $(18.2,22.1)$ & 2.4 & 20. & 16.4 & 23.5 \\
\hline $90 \mathrm{~m}^{2}-109 \mathrm{~m}^{2}$ & 10 & 20.4 & $(19.0,21.9)$ & 2.1 & 20.0 & 16.9 & 24.2 & & 20.0 & $(17.7,22.4)$ & 2.8 & 20.9 & 15.8 & 23.7 \\
\hline HEATING $^{+}$ & & & & & & & & & & & & & & \\
\hline Gas & 57 & 20.2 & $(19.5,20.8)$ & 2.4 & 20.4 & 15.1 & 26.3 & 57 & 19.9 & $(19.2,20.6)$ & 2.5 & 19.9 & 14.1 & 26.0 \\
\hline Gas & $3 r$ & 19.9 & $(19.1,20.6)$ & 2.9 & 19.9 & 14.2 & 26.6 & r & 19.6 & $(18.8,20.3)$ & 2.9 & 19.6 & 11.9 & 26.1 \\
\hline$A S H P$ & & 20.6 & $(18.6,22.6)$ & 3.2 & 19.8 & 16.2 & 27.1 & 13 & 20.7 & $(18.9,22.5)$ & 3.0 & 20.2 & 16.2 & 25.8 \\
\hline ASHP & 12 & 20.6 & $(17.8,23.3)$ & 4.4 & 20.1 & 14.6 & 30.1 & 13 & 20.8 & $(18.5,23.1)$ & 3.8 & 20.0 & 14.0 & 27.9 \\
\hline & & 20.0 & $(17.6,22.5)$ & 0.3 & 20.0 & 19.8 & 20.2 & & 20.7 & NA & NA & NA & NA & NA \\
\hline GSHP & 2 & 19.5 & $(19.0,20.1)$ & 0.1 & 19.5 & 19.5 & 19.6 & 1 & 21.0 & $N A$ & $N A$ & $N A$ & $N A$ & $N A$ \\
\hline & & 20.9 & $(20.0,21.7)$ & 2.2 & 21.1 & 16.0 & 25.3 & & 19.7 & $(18.8,20.6)$ & 2.3 & 19.3 & 15.0 & 24.2 \\
\hline Storage heaters & 29 & 20.5 & $(19.6,21.5)$ & 2.6 & 20.7 & 14.4 & 26.3 & 28 & 19.1 & $(18.1,20.2)$ & 2.7 & 18.9 & 13.3 & 24.5 \\
\hline Electric Unknown & 1 & 19.6 & NA & NA & NA & NA & NA & 2 & 16.8 & $(-13.5,47.1)$ & 3.4 & 16. & 14.4 & 19.2 \\
\hline Electric Unknown & 1 & 18.7 & $N A$ & $N A$ & $N A$ & $N A$ & $N A$ & 2 & 15.5 & $(-22.4,53.4)$ & 4.2 & 15.5 & 12.6 & 18.5 \\
\hline
\end{tabular}


318 3.4. The relationship between dwelling characteristics and indoor temperatures

319 Mean living room and bedroom temperatures, the proportion of occupied hours below the 320 minimum temperature threshold of $18^{\circ} \mathrm{C}$ and mean achieved temperatures were influenced by a 321 number of dwelling characteristics (Tables 4 and 5). During the heating season, there was a general 322 trend towards colder living rooms and bedrooms in older properties, those with solid walls and 323 properties with lower energy efficiency (i.e. SAP) ratings.

324 Tables 6 and 7 indicate the significant differences between dwellings with different characteristics 325 found in relation to room temperatures and median occupied hours below $18^{\circ} \mathrm{C}$, respectively.

Table 1: Significant $(p<0.1)$ results from one-way ANOVA tests with post hoc Tukey HSD test ${ }^{\dagger}$

\begin{tabular}{|c|c|c|c|c|c|c|}
\hline & \multicolumn{3}{|l|}{ Heating season } & \multicolumn{3}{|l|}{ Winter } \\
\hline & $\begin{array}{l}\text { F-statistic } \\
\text { (ANOVA) }\end{array}$ & $\begin{array}{l}\text { Mean difference, } \\
\mathrm{i}-\mathrm{j}^{+} \\
(95 \% \text { C.I.) }\end{array}$ & $\begin{array}{l}\text { Significance } \\
\text { of mean } \\
\text { difference }\end{array}$ & $\begin{array}{l}\text { F-statistic } \\
\text { (ANOVA) }\end{array}$ & $\begin{array}{l}\text { Mean difference, } \\
\mathrm{i}-\mathrm{j}^{+} \\
(95 \% \text { C.I. })\end{array}$ & $\begin{array}{l}\text { Significance } \\
\text { of mean } \\
\text { difference }\end{array}$ \\
\hline \multicolumn{7}{|c|}{ Living room - Occupied hours mean temperature } \\
\hline \multicolumn{7}{|l|}{ YEAR OF BUILD } \\
\hline Pre $1966 / 1982-1995$ & $F(3,100)=5.15$ & $-2.24(-3.90,-0.58)$ & $p=0.004$ & $F(3,100)=5.26$ & $-2.77(-4.74,-0.79)$ & $p=0.002$ \\
\hline 1966-1981/1982-1995 & $F(3,100)=5.15$ & $-1.78(-3.23,-0.33)$ & $p=0.009$ & $F(3,100)=5.26$ & $-2.06(-3.78,-0.34)$ & $p=0.012$ \\
\hline \multicolumn{7}{|l|}{ HEATING } \\
\hline Gas/Storage Heaters & $F(2,95)=3.40$ & $-1.40(-2.67,-0.12)$ & $p=0.029$ & $F(2,95)=2.90$ & $-1.54(-3.07,-0.02)$ & $p=0.047$ \\
\hline \multicolumn{7}{|c|}{ Living room - Mean achieved temperature } \\
\hline \multicolumn{7}{|l|}{ YEAR OF BUILD } \\
\hline Pre 1966/1982-1995 & $F(3,100)=5.06$ & $-2.39(-4.08,-0.69)$ & $p=0.002$ & $F(3,100)=5.06$ & $-2.94(-4.99,-0.89)$ & $p=0.002$ \\
\hline 1966-1981/1982-1995 & $F(3,100)=5.06$ & $-1.65(-3.13,-0.18)$ & $\mathrm{p}=0.022$ & $F(3,100)=5.06$ & $-1.91(-3.70,-0.12)$ & $\mathrm{p}=0.032$ \\
\hline \multicolumn{7}{|c|}{ Bedroom - Occupied hours mean temperature } \\
\hline \multicolumn{7}{|l|}{ FLOOR SPACE } \\
\hline$<50 m^{2} / 50 m^{2}-69 m^{2}$ & & & & $F(3,100)=2.66$ & $-1.82(-3.76,0.12)$ & $\mathrm{p}=0.075$ \\
\hline $50 m^{2}-69 m^{2} / 70 m^{2}-$ & & & & $F(3,100)=2.66$ & $1.59(-0.17,3.34)$ & $\mathrm{p}=0.091$ \\
\hline \multicolumn{7}{|l|}{$89 m^{2}$} \\
\hline \multicolumn{7}{|c|}{ Bedroom - Mean achieved temperature } \\
\hline \multicolumn{7}{|l|}{ FLOOR SPACE } \\
\hline$<50 m^{2} / 50 m^{2}-69 m^{2}$ & & & & $F(3,100)=3.26$ & $-2.17(-4.22,-0.12)$ & $p=0.034$ \\
\hline $50 m^{2}-69 m^{2} / 70 m^{2}-$ & & & & $F(3,100)=3.26$ & $1.83(-0.02,3.69)$ & $\mathrm{p}=0.054$ \\
\hline $89 m^{2}$ & & & & & & \\
\hline
\end{tabular}

${ }^{\dagger}$ Subcategory comparisons are listed in the order $\mathrm{i} / \mathrm{j}$ where $\mathrm{i}$ is the first subcategory in the comparison and $\mathrm{j}$ is the second. Mean difference between subcategories with significance obtained from post hoc Tukey HSD test.

329 Table 7: Significant $(p<0.1)$ results from Kruskal-Wallis test with pairwise comparison (Dunn's 330 procedure)

Heating season $\quad$ Winter




$\begin{array}{llllll}\text { Median } & \text { H-statistic } & \text { Adjusted } & \text { Median } & \text { H-statistic } & \text { Adjusted } \\ \text { occupied hours } & \text { (Kruskal- } & \text { significance } & \text { occupied hours } & \text { (Kruskal- } & \text { significance } \\ <18^{\circ} \mathrm{C} \mathrm{i}, \mathrm{j}^{\dagger} & \text { Wallis) } & \text { (Dunn's) } & <18^{\circ} \mathrm{C} \mathrm{i,j^{ \dagger }} & \text { Wallis) } & \text { (Dunn's) }\end{array}$

\begin{tabular}{|c|c|c|c|c|c|c|}
\hline \multicolumn{7}{|l|}{ Living room } \\
\hline \multicolumn{7}{|l|}{ YEAR OF BUILD } \\
\hline Pre 1966/1982-1995 & 1013,214 & $H(3)=9.95$ & $p=0.052$ & 644,79 & $H(3)=10.46$ & $p=0.030$ \\
\hline 1966-1981/1982-1995 & 1157,214 & $H(3)=9.95$ & $p=0.042$ & 566,79 & $H(3)=10.46$ & $p=0.040$ \\
\hline \multicolumn{7}{|l|}{ HEATING } \\
\hline Gas/Storage Heaters & 950,241 & $H(2)=5.48$ & $p=0.060$ & 575,91 & $H(2)=5.71$ & $p=0.055$ \\
\hline \multicolumn{7}{|l|}{ Bedroom } \\
\hline \multicolumn{7}{|l|}{ FLOOR SPACE } \\
\hline $50 m^{2}-69 m^{2} / 70 m^{2}-89 m^{2}$ & & & & 288,734 & $H(3)=7.58$ & $p=0.078$ \\
\hline \multicolumn{7}{|l|}{ WALL CONSTRUCTION } \\
\hline Filled cavity/Solid - Insulated & & & & 409,881 & $H(2)=5.62$ & $p=0.053$ \\
\hline
\end{tabular}

${ }^{\dagger}$ Subcategory comparisons are listed in the order $\mathrm{i} / \mathrm{j}$ where $\mathrm{i}$ is the first subcategory in the comparison and $\mathrm{j}$ is the second

332 Living rooms in pre-1966 dwellings had a significantly lower mean temperature compared to 1982-

3331995 dwellings $\left(18.1^{\circ} \mathrm{C}\right.$ cf. $\left.20.3^{\circ} \mathrm{C}, \mathrm{p}=0.004\right)$, and a significantly lower mean achieved temperature

334 (19.3 ${ }^{\circ} \mathrm{C}$ cf. $\left.21.7^{\circ} \mathrm{C}, \mathrm{p}=0.002\right)$. Compared to $1982-1995$ dwellings, dwellings built in 1966-1981 had a

335 significantly lower mean living room temperature $\left(18.5^{\circ} \mathrm{C}\right.$ cf. $\left.20.3^{\circ} \mathrm{C}, p=0.009\right)$ and a significantly

336 lower mean achieved living room $\left(20.1^{\circ} \mathrm{C}\right.$ cf. $\left.21.7^{\circ} \mathrm{C}, \mathrm{p}=0.0022\right)$. There were statistically significant

337 differences in the median number of hours below $18^{\circ} \mathrm{C}$ between the pre 1966 and 1982-1995 build

338 categories $(p=0.052)$, and 1966-1981 and 1982-1995 build categories ( $p=0.042)$ with a lower median

339 number of hours below $18^{\circ} \mathrm{C}$ for $1982-95$ builds. Living rooms heated by storage heaters had a

340 significantly higher mean temperature $(p=0.029)$ and a lower median number of hours below $18^{\circ} \mathrm{C}$

$341(p=0.060)$ compared to those heated by gas. The general trend for living rooms was similar when

342 significance tests were performed for the winter only.

343 For bedrooms, the following results were significant for the winter period only. Bedrooms in

344 dwellings with floor space $50 \mathrm{~m}^{2}-69 \mathrm{~m}^{2}$ had a lower median number of hours below $18^{\circ} \mathrm{C}$ than those

345 with floor space $70 \mathrm{~m}^{2}-89 \mathrm{~m}^{2}(\mathrm{p}=0.078)$ and bedrooms in dwellings with filled cavity walls had a

346 lower median number of hours below $18^{\circ} \mathrm{C}$ than those with solid insulated walls ( $p=0.053$ ).

347 There was no significant difference between the indoor temperatures depending on the property

348 type, energy efficiency rating (i.e. SAP band), built form or flat level (for flats). 


\subsection{Comparison of the findings with previous studies}

351

352

353

Previous studies investigating wintertime indoor temperatures in English dwellings have been conducted over different time periods, under different weather conditions and with various sample characteristics. Analyses have used different occupied (or heating) hours (Huebner et al., 2013a; Huebner et al., 2013b; Kane et al., 2015; Hamilton et al., 2017), or have used different techniques to check for outliers and have not used "assumed occupied hours" (DECC, 2013b; Kane et al., 2015; Huebner et al., 2019). Studies have also reported temperatures differently; some have reported monthly means, others have used the winter period or the heating season. Although these differences make it difficult to directly compare the internal temperatures found in this study with previous studies, analysis of temperatures for both the heating season and winter enable a wider comparison to be made. Winter and heating season investigation periods for all previous studies were presented in Table 1.

Table 8: Summary of mean temperatures and percentage of rooms with mean temperatures below $18^{\circ} \mathrm{C}$ for the current and previous studies containing social housing dwellings

\begin{tabular}{|c|c|c|c|c|c|c|c|}
\hline & \multicolumn{3}{|c|}{ Heating season } & \multicolumn{4}{|l|}{ Winter } \\
\hline & $\begin{array}{l}\text { Living room } \\
\text { Mean } \\
\text { temperature } \\
\left({ }^{\circ} \mathrm{C}\right)\end{array}$ & $\begin{array}{l}\text { Bedroom } \\
\text { Mean } \\
\text { temperature } \\
\left({ }^{\circ} \mathrm{C}\right)\end{array}$ & $\begin{array}{l}\text { Percentage } \\
\text { of living } \\
\text { rooms with } \\
\text { Mean } \\
\text { temperature } \\
<18^{\circ} \mathrm{C}\end{array}$ & $\begin{array}{l}\text { Living room } \\
\text { Mean } \\
\text { temperature } \\
\left({ }^{\circ} \mathrm{C}\right)\end{array}$ & $\begin{array}{l}\text { Bedroom } \\
\text { Mean } \\
\text { temperature } \\
\left({ }^{\circ} \mathrm{C}\right)\end{array}$ & $\begin{array}{l}\text { Percentage of } \\
\text { living rooms } \\
\text { with Mean } \\
\text { temperature } \\
<18^{\circ} \mathrm{C}\end{array}$ & $\begin{array}{l}\text { Percentage of } \\
\text { bedrooms } \\
\text { with room } \\
\text { Mean } \\
\text { temperature } \\
<18^{\circ} \mathrm{C}\end{array}$ \\
\hline Current study & 19.0 & 18.7 & $33 \%$ & 18.6 & 18.2 & $39 \%$ & $46 \%$ \\
\hline DECC (2013b) & $\begin{array}{l}20.3(\mathrm{LA})^{\mathrm{a}} \\
20.0 \text { (RSL) }^{\mathrm{b}}\end{array}$ & $\begin{array}{l}19.3(\mathrm{LA})^{\mathrm{a}} \\
19.1 \text { (RSL) }^{\mathrm{b}}\end{array}$ & $26 \%^{*}$ & & & & \\
\hline $\begin{array}{l}\text { Hamilton et al. } \\
(2017)^{+}\end{array}$ & & & & $\begin{array}{l}20.2(\mathrm{LA})^{a} \\
19.5(\mathrm{RSL})^{b}\end{array}$ & $\begin{array}{l}18.9(\mathrm{LA})^{a} \\
18.5(\mathrm{RSL})^{\mathrm{b}}\end{array}$ & & \\
\hline Kane et al. (2015)* & & & & $18.5^{*}$ & $17.4^{*}$ & & \\
\hline Huebner et a & & & & $18.9^{*}$ & $18.1^{*}$ & $33 \%^{*}$ & $45 \%^{*}$ \\
\hline
\end{tabular}

(2018)*

*values reported for the whole sample including social and non-social housing

${ }^{+}$Indoor temperatures were standardised to an outdoor temperature of $5^{\circ} \mathrm{C}$

a Local Authority (LA), ${ }^{\text {b }}$ Registered Social Landlords (RSL)

Table 8 gives a summary of mean temperatures and percentage of living rooms and bedrooms with mean temperatures below $18^{\circ} \mathrm{C}$ for the current and previous studies which contained social housing (see Table 1) where such results were available. Generally, mean temperatures for the current study were lower than those for other studies except for the study by Kane et al. (2015) which was 
undertaken during a colder than average winter (where the average external temperature was $2.3^{\circ} \mathrm{C}$ ) for 249 homes in a similar region (Leicester, East Midlands).

The mean winter living room temperature for the current study is comparable with the $18.5^{\circ} \mathrm{C}$ reported by Kane et al. (2015) and the mean winter bedroom temperature for the current study is $0.6^{\circ} \mathrm{C}$ warmer than the $17.4^{\circ} \mathrm{C}$ also reported by Kane et al. (2015). In addition to Table 8, the overall mean achieved temperature for living rooms of $20.4^{\circ} \mathrm{C}$ for the current study is $0.5^{\circ} \mathrm{C}$ lower than the $20.9^{\circ} \mathrm{C}$ from the study of Kane et al. (2015) (where the mean achieved temperature was reported for living rooms only).

The proportion of living rooms with mean heating season temperatures and mean winter temperatures below $18^{\circ} \mathrm{C}$ are higher in this study compared to EFUS 2011 (DECC, 2013b) and EFUS 2011 (Huebner et al., 2018), respectively. It is noted that no distinction for occupied hours was made for the former study, whereas the current study assumed occupied hours of 8am to 8pm for living rooms (Section 2.6).

The proportion of bedrooms with mean winter temperatures below $18^{\circ} \mathrm{C}$ is very similar to EFUS 2011 (46\% cf. 45\%) (Huebner et al., 2018). Additionally, the proportion of bedrooms with mean winter temperatures below $18^{\circ} \mathrm{C}$ is lower than the proportion of bedrooms in low income social housing flats in Portsmouth where Teli et al. (2016) found that more than half of bedrooms had mean wintertime indoor temperatures below $18^{\circ} \mathrm{C}$, mainly due to households being unable to afford to heat their homes sufficiently. Huebner et al. (2019) found that the proportion of hours at $18^{\circ} \mathrm{C}$ or more in living rooms of local authority rented properties was higher relative to privately owned dwellings.

Where possible, comparisons were also made with previous studies with regards to the relationship between dwelling characteristics and indoor temperatures. In the current study, a trend was apparent in both living rooms and bedrooms, of warmer rooms having a higher SAP rating, although this was not significant. This is in agreement with both EFUS 2011 (DECC, 2013b) and Hamilton et al. (2017) which both found properties with a higher SAP rating were warmer. There were several instances where living rooms in dwellings for the 1982-95 build period were significantly warmer than earlier builds, and had fewer hours below $18^{\circ} \mathrm{C}$. This is in agreement with Hamilton et al. (2017) which found evidence of older dwellings being cooler. Oreszczyn et al. (2006) found bedrooms in dwellings built after 1966 to be warmer than those built before. In terms of floor space, the 50-69 $\mathrm{m}^{2}$ category was significantly warmer for bedrooms in winter. In the EFUS study, for all dwellings, those with a useable floor area $<50 \mathrm{~m}^{2}$ exhibited the highest mean temperatures during the heating season for both living 
rooms and bedrooms, a result echoed by Hamilton et al. (2017) when temperatures were standardised to a $5^{\circ} \mathrm{C}$ outdoor air temperature.

The following findings were unique to this study as they were not investigated or observed in the previous studies. Bedrooms in properties with insulated solid walls were significantly cooler and had fewer hours below $18^{\circ} \mathrm{C}$ compared to those with filled cavity walls, although this effect was not apparent in living rooms. Kane et al (2015) found that solid-walled dwellings were significantly cooler than dwellings with filled cavity walls and Hamilton et al (2017) found that "solid as built" walls were cooler than average regarding all wall constructions. However, a comparison between social housing dwellings with solid insulated walls and those filled cavity walls has not previously been reported.

Gas heated living rooms were significantly cooler than those heated by storage heaters for both the heating season and winter, with a greater number of occupied hours below $18^{\circ} \mathrm{C}$. Hamilton et al. (2017) found no significant difference between living room temperatures between dwellings heated by boilers with radiators and those heated by storage radiators, although bedrooms in dwellings heated with radiators were warmer than those heated by storage radiators $(p=0.057)$. The study contained around $22 \%$ social housing dwellings. Other studies have compared indoor temperatures for dwellings with and without central heating (Kane et al, 2015), (DECC 2013b), (Huebner et al. 2019) with no distinction for storage heating.

Finally, the vast majority of heating season mean temperatures were warmer than their winter counterparts, as might be expected, although not significantly. There were only two instances where the mean room temperature over the heating season was higher than that over winter (Table 4), and these occurred within property categories with a sample size of one. The investigation of indoor temperatures for social housing by property characteristics for both the winter and heating season is unique to this study.

\subsection{Implications for health and wellbeing}

With over four million social housing dwellings in England accommodating a higher proportion of vulnerable people compared to rest of the housing stock, the health and wellbeing of social housing residents are of prime concern. While the implications of cold homes in winter are less significant for younger healthy people with sufficient bedding and clothing, occupants at risk, particularly those over 65 years of age or with pre-existing medical conditions, are expected to suffer the most as blood pressure increases as temperatures fall below $18^{\circ} \mathrm{C}$ which increases the risk of blood clotting (Jevons et al., 2016). In this study, over $38 \%$ of living rooms and over $45 \%$ of bedrooms during occupied hours of the winter months (i.e. December-February) had mean temperatures below $18^{\circ} \mathrm{C}$ 
which is the minimum temperature threshold during occupied hours as recommended by the Cold Weather Plan for England (Public Health England, 2018). The applicability of the findings of this study to the UK social housing sector at a national scale, and the alignment with existing studies suggest that a vast majority of English social housing dwellings could be at serious risk of being underheated. Considering the higher vulnerability of social housing occupants, attention needs to be focused on developing appropriate methods to assess underheating risk in social housing dwellings including effective minimum temperature thresholds for specific households and occupants.

\subsection{Implications for policy makers}

Investigation of the wintertime indoor temperatures in social housing dwellings during the heating season revealed that there was a general trend towards colder living rooms and bedrooms in older properties, properties with lower SAP ratings and those with solid walls. Dwellings with solidinsulated walls particularly had a significantly lower mean bedroom temperature compared to bedrooms in dwellings with filled cavity walls. Such trends suggest that homes at risk of being underheated are older homes, those with solid walls and low SAP ratings. Moreover, dwellings which used gas central heating had significantly lower mean temperature and had higher number of hours when living rooms were below $18^{\circ} \mathrm{C}$ compared to dwellings heated with storage heaters. This might be due to their old and inefficient heating systems with poor heating controls. Upgrades to zonal heating controls which enables individual rooms to be heated only when occupied could be a cost-effective solution (Lomas et al., 2018; Beizaee et al., 2015). A study by Bray et al. (2017) in the North-East of England showed that retrofitting social housing with new combi-boilers and doubleglazed windows reduced the National Health Services (NHS) costs by $16 \%$ per household. As a result of the refurbishments, a third of the households no longer exhibited signs of fuel poverty. Hence, it can be concluded with high confidence that refurbishing social housing dwellings can significantly improve the households' thermal comfort and health conditions, and the policies need to prioritise the older social housing dwellings with lower SAP ratings and solid wall constructions.

\subsection{Limitations}

Several of the property categories for the current study have a small sample size. For instance, there were only ten dwellings in SAP band B and band E as appose to 35 dwellings in band C and 30 in band D; majority of the dwellings had cavity external walls $(n=96)$ and only a few had solid wall constructions $(n=7)$; additionally there were only five detached dwellings in the investigated sample compared to 37 terraced and 36 semi-detached dwellings. With larger representation, the relationship between internal temperature and category variables could be more apparent. 
The $p$ value indicates the probability of observing a difference which is at least as large as the observed results, assuming that the null hypothesis is true. A lower $p$ value indicates a greater statistical significance of the observed difference. In this study, in order to avoid missing a factor that could play an important role in determining winter indoor temperatures in social housing dwellings, a higher $p$ value of 0.1 was considered compared to a p value of 0.05 which is being used more often. There is a little risk that this could have resulted in identifying a factor as significant when it is not. Therefore, where results significant at $0.05 \leq p<0.1$ level have been stated, such significance may be considered as weak.

There are several areas where additional information was not available (i.e. employment, household composition, age, and external wall insulation type) which could have aided the explanation of results, particularly for the individual properties which exhibited low indoor temperatures for longer hours of occupied hours.

The sensors used to measure indoor temperatures had an accuracy of $+/-1^{-} \mathrm{C}$. In addition, the exact location of sensors in each room was not known and the occupied hours assumed for living room and bedrooms may be different to how the rooms were occupied. Although a calibration exercise was conducted to ensure the reliability and accuracy of sensor measurements, these combined effects may result in a difference between the temperatures recorded by sensors and the actual temperatures felt by occupants. Moreover, the difficulty of deploying multiple sensors in each room which are all suitably shielded from radiant and conductive sources means that the temperatures recorded by the single sensor in each room may be different to whole space air temperature or operative temperature of the rooms.

\section{Conclusions}

This study presented one of the largest surveys of wintertime indoor temperatures in social housing dwellings in central England. Indoor temperatures were measured in 104 living rooms and 104 main bedrooms from 124 social housing dwellings and analysed separately for heating season and winter 2015. During the heating season, the mean living room and bedroom temperatures when occupied were $19.0^{\circ} \mathrm{C}$ and $18.7^{\circ} \mathrm{C}$, respectively. Indoor temperatures were, in general, lower during the winter with mean living room and bedroom temperatures of $18.6^{\circ} \mathrm{C}$ and $18.2^{\circ} \mathrm{C}$, respectively. The mean living room temperature during the winter was $2.4^{\circ} \mathrm{C}$ lower than the minimum temperature recommended by the WHO . 
respectively below $18^{\circ} \mathrm{C}$ during winter. $18^{\circ} \mathrm{C}$ is recommended by the Public Health England as a reasonable minimum indoor temperature for homes in winter which poses minimal risk to the health of a sedentary person, wearing suitable clothing. The study identified the need for a robust method to assess the risk of underheating in dwellings and particularly those which accommodate vulnerable occupants.

Significant variations were observed between living room and bedroom temperatures in dwellings with different characteristics. Older dwellings built before 1982 were found to be at significantly highest risk of having cold rooms and should be prioritised for refurbishment by the social housing providers. The study also found that living rooms in dwellings with gas central heating were significantly colder than those heated by storage heaters. The low indoor temperatures observed during a typical heating season and winter in England are of a prime concern as social housing dwellings accommodate some of the most vulnerable groups who are at the highest risk of cold homes.

\section{Acknowledgements}

The provision of internal temperature data and property information by EMH homes is gratefully acknowledged. The research would not have been possible without the cooperation of the many households who kindly participated in this study. This research did not receive any specific grant from funding agencies in the public, commercial, or not-for-profit sectors.

\section{References}

518 Adam, S., Chandler, D., Hood, A., Joyce, R. (2015) 'Social housing in England: a survey', Institute for 519 Fiscal studies. Available online at: https://www.ifs.org.uk/uploads/publications/bns/BN178.pdf 520 [Accessed 02.05.2020].

521 Beizaee, A., Allinson, D., Lomas, K.J., Foda, E., Loveday, D.L. (2015) 'Measuring the potential of zonal 522 space heating controls to reduce energy use in UK homes: The case of un-furbished 1930s dwellings'

523 Energy and Buildings, 91, pp. 29-44. https://doi.org/10.1016/i.enbuild.2015.01.040

524 Bray, N., Burns, P., Jones, A. et al. (2017) 'Costs and outcomes of improving population health 525 through better social housing: a cohort study and economic analysis', International Journal of Public 526 Health, 62, 1039-50. https://doi.org/10.1007/s00038-017-0989-y BRE (2012) 'The Government's Standard Assessment Procedure for Energy Rating of Dwellings', 2012 edition, UK Building Research Establishment on behalf of the UK Department of Energy and Climate 
$530 \quad$ [Accessed 02.05.20]

531 DECC (2013a) 'Fuel Poverty: A Framework for Future Action', Department of Energy and Climate 532 Change. Available online at:

533 https://assets.publishing.service.gov.uk/government/uploads/system/uploads/attachment data/file 534 L211180/FuelPovFramework.pdf [Accessed 02.05.2020]

535 DECC (2013b) BRE Energy Follow-Up Survey (EFUS) 2011. Department of Energy \& Climate Change.

536 https://www.gov.uk/government/statistics/energy-follow-up-survey-efus-2011 [Accessed

$537 \quad 02.05 .2020]$

538 Fowler, T., Southgate, R., Waite, T., Harrell, R., Kovats, S., Bone, A. et al. (2015) 'Excess winter deaths 539 in Europe: a multi-country descriptive analysis', European Journal of Public Health, 25(2), pp. 339-45. 540 https://doi.org/10.1093/eurpub/cku073

541 Gupta, R., and Kapsali, M. (2016) 'Empirical assessment of indoor air quality and overheating in low-

542 carbon social housing dwellings in England, UK', Advances in Building Energy Research, 10(1), pp. 46-

543 68. https://doi.org/10.1080/17512549.2015.1014843

544 Hamilton, I.G., O’Sullivan, A., Huebner, G., Oreszczyn, T., Shipworth, D., Summerfield, A. (2017) ‘Old

545 and cold? Findings on the determinants of indoor temperatures in English dwellings during cold 546 conditions' Energy and Buildings, 141, pp. 142-57. https://doi.org/10.1016/j.enbuild.2017.02.014

547 Healy, J.D. (2003) 'Excess winter mortality in Europe: a cross country analysis identifying key risk 548 factors', Journal of Epidemiology \& Community Health, 57(10), pp. 784-789.

549 http://dx.doi.org/10.1136/jech.57.10.784

550 Huebner, G.M., Chalabi, Z., Hamilton, I., Oreszczyn, T. (2019) ‘Determinants of winter indoor

551 temperatures below the threshold for healthy living in England', Energy and Buildings, 202, article

552 109399. https://doi.org/10.1016/j.enbuild.2019.109399

553 Huebner, G.M., Hamilton, I., Chalabi, Z., Shipworth, D., Oreszczyn, T. (2018) 'Comparison of indoor 554 temperatures of homes with recommended temperatures and effects of disability and age: an 555 observational, cross-sectional study', BMJ Open, 8(5), e021085. http://dx.doi.org/10.1136/bmjopen$556 \quad \underline{2017-021085}$

557 Huebner, G.M., McMichael, M., Shipworth, D., Shipworth, M., Durand-Daubin, M., Summerfield, A.

558 (2013a) 'The reality of English living rooms-a comparison of internal temperatures against common 
model assumptions', Energy and Buildings, 66, pp.688-96. https://www.sciencedirect.com/science/article/pii/S0378778813004131

Huebner, G.M., McMichael, M., Shipworth, D., Shipworth, M., Durand-Daubin, M., Summerfield, A. (2013b) 'Heating patterns in English homes: comparing results from a national survey against common model assumptions, Building and Environment, 70, pp. 298-305.

\section{http://dx.doi.org/10.1016/j.buildenv.2013.08.028}

(IMB, 2017) IBM Corp. Released 2017. IBM SPSS Statistics for Windows, Version 25.0. Armonk, NY: IBM Corp.

Jevons, R., Carmichael, C., Crossley, A., Bone, A. (2016) ‘Minimum indoor temperature threshold recommendations for English homes in winter - A systematic review', Journal of Public Health, 136, pp. 4-12. https://doi.org/10.1016/j.puhe.2016.02.007.

Jones, R.V., Fuertes, A., Boomsma, C., Pahl, S. (2016) 'Space heating preferences in UK social housing: A socio-technical household survey combined with building audits', Energy and Building, 127, PP.382-98. https://doi.org/10.1016/j.enbuild.2016.06.006

Kane, T., Firth, S. K., and Lomas, K. J. (2015) 'How are UK homes heated? A citywide, socio-technical survey and implications for energy modelling', Energy and Building, 86, pp. 817-32.

https://doi.org/10.1016/j.enbuild.2014.10.011

Liddell, C. \& Morris, C. (2010) 'Fuel poverty and human health: A review of recent evidence', Energy Policy, 38, PP. 2987-2997. https://doi.org/10.1016/j.enpol.2010.01.037

Lomas, K.J, Oliviera, S., Warren, P., Haines, V.J., Chatterton, T., Beizaee, A., Prestwood, E., Gething, B. (2018). 'Do Domestic Heating Controls Save Energy? A Review of the Evidence' Journal of Renewable \& Sustainable Energy Reviews, 93, pp. 52-75. https://doi.org/10.1016/j.rser.2018.05.002

Met Office (2006) ‘MIDAS: UK Hourly Weather Observation Data. NCAS British Atmospheric Data Centre', 02.05.2020.Avaliable at: $\underline{\text { https://catalogue.ceda.ac.uk/uuid/916ac4bbc46f7685ae9a5e10451bae7c }}$ MHCLG (2020) 'Statistical data set: Stock profile', Ministry of Housing, Communities \& Local Government. Available online at: https://www.gov.uk/government/statistical-data-sets/stockprofile [Accessed 02.05.20] 

dwellings in central England. Building and Environment, 176, Article 106814.

ONS (2019a) 'Excess winter mortality in England and Wales: 2018 to 2019 (provisional) and 2017 to 2018 (final)', Office of National Statistics. Available at:

https://www.ons.gov.uk/peoplepopulationandcommunity/birthsdeathsandmarriages/deaths/bulleti ns/excesswintermortalityinenglandandwales/2018to2019provisionaland2017to2018final [Accessed on 02.05.2020]

ONS (2019b) 'Comparing affordable housing in the UK: April 2008 to March 2018', Office for National Statistics. Available at:

https://www.ons.gov.uk/peoplepopulationandcommunity/housing/articles/comparingaffordableho usingintheuk/april2008tomarch2018 [Accessed on 02.05.2020]

Oreszczyn, T., Hong, S.H., Ridley, I., et al. (2006) 'Determinants of winter indoor temperatures in low income households in England', Energy and Buildings, 38(3), pp.245-52.

602 Orsis (2020) 'Orsis CO2SS Combined Temperature, Humidity \& CO2 Sensor', Available online at:

603 https://www.orsis.co.uk/products/co2ss/[Accessed 02.05.20]

604 Public Health England (2018) 'The Cold Weather Plan for England: Protecting health and reducing 605 harm from cold weather, Available online at:

606 https://assets.publishing.service.gov.uk/government/uploads/system/uploads/attachment data/file 607 1748492/the cold weather plan for england 2018.pdf [Accessed: 02.05.2020]

608 Shipworth, M., Firth, S.K., Gentry, M., Wright, J.A., Shipworth, D., Lomas, K.J. (2010) 'Central heating 609 thermostat settings and timing: building demographics', Building Research \& Information, 38, pp.

610 50-69. https://doi.org/10.1080/09613210903263007

611 Teli, D., Dimitriou, T., James, P.A.B., Bahaj, A.S., Ellison, L., Waggott, A. (2016) 'Fuel poverty-induced 612 'prebound effect' in achieving the anticipated carbon savings from social housing retrofit', Building 613 Services Engineering Research and Technology, 37, pp.176-93.

\section{4 https://doi.org/10.1177/0143624415621028}

615 The R Foundation (2018) 'The R Foundation for Statistical Computing R version 3.5.1 (2018-07-02)'

616 Available online at: https://cran.r-project.org/bin/windows/base/old/3.5.1/ [Accessed on 01.02.19] 

measures, Fact sheet No. EURO/04/03, Copenhagen, Rome, 29 September 2003, WHO, Geneva. 